\title{
Anticarcinogenic Effects of $\alpha$-Mangostin: A Review
}

\author{
Authors \\ Kuo-jun Zhang ${ }^{1}$, Qin-lan Gu ${ }^{2}$, Kan Yang ${ }^{1}$, Xian-jun Ming ${ }^{1}$, Jin-xin \\ Wang ${ }^{1}$ \\ Affiliations \\ 1 Key Laboratory of Drug Design and Optimization of Jiangsu \\ Province, China Pharmaceutical University, Nanjing, China \\ 2 Higher Vocational and Technical College, China Pharmaceutical \\ University, Nanjing, China \\ Key words \\ $\alpha$-mangostin, Clusiaceae, Garcinia mangostana, molecular mechanism, \\ pharmacokinetics, toxicology \\ received June 21,2016 \\ revised October 10,2016 \\ accepted October 16, 2016 \\ Bibliography \\ DOI http://dx.doi.org/10.1055/s-0042-119651 \\ Published online November 4, 2016 | Planta Med 2017; 83: 188-202 \\ (c) Georg Thieme Verlag KG Stuttgart · New York | ISSN 0032-0943 \\ Correspondence \\ Prof. Dr. Jin-xin Wang \\ Key Laboratory of Drug Design and Optimization of Jiangsu Province, \\ China Pharmaceutical University \\ Tongjiaxiang Road 24, Nangjing 210009, China \\ Phone: + 8602583271414 , Fax: + 8602583271564 \\ jinxinwang@163.com
}

(P) Supporting information available online at http://www.thieme-connect.de/products

\section{ABSTRACT}

Cancer chemoprevention is a promising strategy taken to block, reverse, or retard carcinogenesis. $\alpha$-Mangostin, a natural xanthone isolated from the pericarps of mangosteen, represents one of the most studied chemopreventive agents. This compound has been reported to interfere with all the major stages of carcinogenesis: initiation, promotion, and progression. A number of mechanisms have been proposed for its anticarcinogenic activities. This review summarizes the current knowledge on the mechanisms that contribute to the observed activity of $\alpha$-mangostin related to (i) modulation of carcinogenic biotransformation and mitigation of oxidative damage, (ii) induction of growth arrest and apoptosis, (iii) suppression of angiogenesis and metastasis, and (iv) combination with clinical chemotherapy drugs enhancing their efficacy and decreasing the toxic side effects. In addition, pharmacokinetic and toxicological studies of $\alpha$-mangostin have also been highlighted in this review. Despite an overwhelming amount of knowledge in preclinical studies, there was almost no translation of $\alpha$-mangostin into the clinic. It is hoped that continuous extensive and profound research will lead to the application of $\alpha$-mangostin from experimental studies to evidence-based, clinically applicable pharmacotherapy.

\section{Introduction}

Cancer is a major leading cause of death worldwide. The American Cancer Society reported that nearly 577190 cancer patients died and more than 1.6 million new cases occurred in the year 2012 only in USA [1]. More than $70 \%$ of all cancer deaths have occurred in low- and middle-income countries. The global burden of cancer will continue to increase because of aging and growing urbanization as well as accumulated adoption of a cancer-associated lifestyle like smoking, sedentary habits, and westernized diets [2]. It is estimated that there would be about 22 million new cancer cases and more than 13 million deaths worldwide by 2030 according to the WHO report [3].

Cancer is a multifactorial disease typically occurring over an extended period beginning with an initiation phase followed by promotion and progression phases. During the carcinogenic process, a cell acquires essential alterations conferring the progressive transformation of normal cells into cancer cells. The cellular alterations include evading growth suppressors and apoptosis, selfsufficiency in growth signals, uncontrolled replicating potential as well as sustained angiogenesis, tissue invasion, and metastasis
[4]. Over the past decades, significant progress has been achieved in our understanding of the molecular biology of cancer. Nevertheless, this deadly disease has not been conquered yet. The contemporary clinical therapies, including radiotherapy, chemotherapy, surgery, and immunosuppression, offer limited benefits to cancer patients due to metastasis, chemoresistance, or toxicity issues $[5,6]$. Obviously, there is an urgent need to develop alternative treatment modalities for cancer. Chemoprevention, referred to the utilization of nontoxic chemical entities to block, reverse, or retard carcinogenesis, has emerged as an alternative but a more pragmatic strategy for the management of cancer. This approach has been shown great success, and the United States Food and Drug Administration has approved ten agents for cancer prevention, such as the identification and development of tamoxifen and raloxifene for reducing the risk of breast cancer, valrubicin for treatment of preinvasive bladder cancer, and a variety of topical and systemic agents that effectively treat preinvasive neoplastic lesions of the skin [7]. Epidemiological and experimental studies suggest that regular consumption of fruits and vegetables is a relatively practical strategy to reduce the risk of cancer [8]. Many non-nutritive substances derived from a plant-based diet, such as resveratrol, curcumin, sulforaphane, genistein, epigallocatechin- 


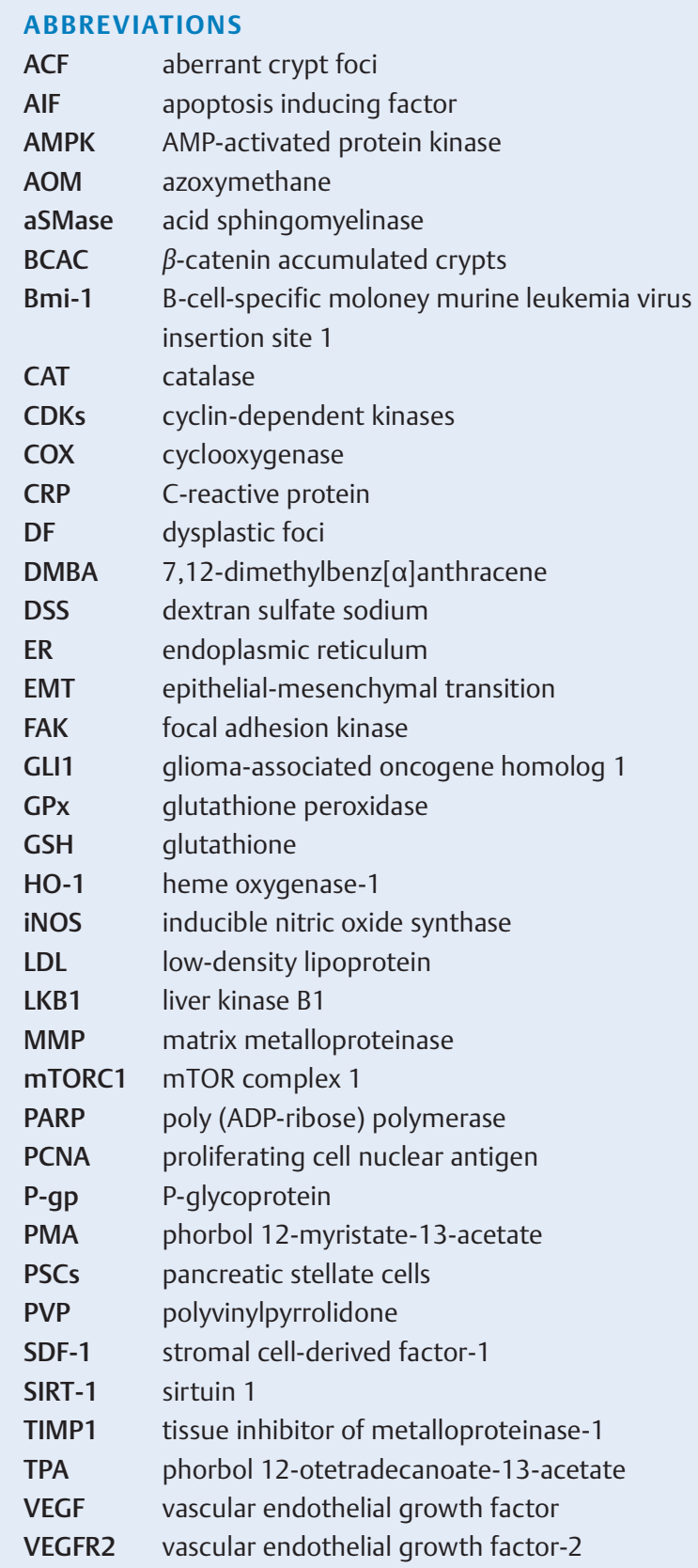

3-gallate (EGCG), gingerol, and caffeic acid phenyl ester, commonly termed "phytochemicals", have been identified as promising cancer chemopreventive agents [9]. According to the conventional classification originally proposed by Lee Wattenberg, these chemopreventive agents are generally classified into two main categories: (i) blocking agents that prevent the occurrence of the damage induced by a carcinogen in the initiation phase, and (ii) suppressing agents that control or reverse the damage in the promotion or progression phase [10]. In addition, some agents that intervene in all three stages of carcinogenesis are classified into both categories, and are considered as more promising molecules for cancer chemoprevention due to their multiple interventions.
Mangosteen (Garcinia mangostana L.) belongs to the family Clusiaceae and is known as "the queen of fruits" for its delicious taste. The pericarps of mangosteen have long been used in different countries (Malaysia, Indonesia, The Philippines, Sri Lanka, Thailand, etc.) for medicinal purposes, including treatment of abdominal pain, dysentery, diarrhea, suppuration, infected wound, and chronic ulcer [11]. Recently, numerous dietary supplements, beverages, and food products manufactured from mangosteen fruits are increasingly popular because of their proposed role in improving human health $[12,13]$. $\alpha$-Mangostin ( $\alpha$-MG; $>$ Fig. 1 ), the most abundant xanthone derived from the pericarps of mangosteen (78\% content), is one of the most studied chemopreventive phytochemicals. $\alpha$-MG has been reported to possess a variety of pharmacological properties, such as antioxidant, antiinfective, anticarcinogenic, and antidiabetic activities, as well as neuroprotective, hepatoprotective, and cardioprotective properties, among which the anticarcinogenic activity is the most promising $[14,15]$. A great deal of evidence from in vitro and in vivo studies demonstrated that $\alpha$-MG works on all of the major stages of tumor growth: initiation, promotion, and progression. $\alpha$-MG acts as a blocking agent by the modulation of enzymes involved in the metabolic activation and excretion of carcinogens, resistance to oxidative damage, and attenuation of inflammatory response, while the inhibition of cell proliferation through modulating cell cycle regulatory machinery, induction of apoptotic effects on damaged and transformed cells, and blockage of angiogenic and metastatic processes of tumor cells contribute to its potential as a suppressing agent. A remarkable progress in interpreting the multiple mechanisms behind the anticarcinogenic activities of $\alpha$-MG has been achieved over the past decades. Understanding how $\alpha$ MG exerts its effects might provide new therapeutic strategies or avenues for the design and development of more potent drugs to efficiently control cancer. In this review, we examine the current knowledge on the mechanism-based in vitro and in vivo studies about the anticarcinogenic activities of $\alpha-\mathrm{MG}$, and integrate these modes of action as potential examples to provide how $\alpha$-MG could prevent carcinogenesis.

\section{Antitumor Activity of Mangostin in Animal Models}

The direct evidence of chemopreventive effects of dietary phytochemicals always comes from cell culture systems and animal models, as it is difficult to assess the real impact on human health [16]. In particular, animal models may provide more convincing evidence, and $\alpha$-MG has been reported to exert anticarcinogenic activities in several animal models of experimentally induced carcinogenesis ( $\triangleright$ Table 1 ). Arakaki et al. [17] established a mouse colon carcinogenesis model employing AOM as the initiating carcinogen and DSS as the promoting agent. They observed that dietary $\alpha$-MG significantly decreased the PCNA positive index of colon tumors and increased the caspase-3 positive index of them. In another similar study conducted by Nabandith et al. [18], a short-term dietary administration of crude $\alpha$-MG to rat models of 1,2-dimethylhydrazine-induced colon carcinogenesis showed a marked reduction of the formation of ACF in the colon and de- 
crease of both DF and $\beta$-catenin accumulation in the crypts in a dose-dependent fashion. These results suggest that $\alpha$-MG has potential as a chemopreventive agent by inhibition of cell proliferation and induction of apoptosis against preneoplastic cells. Besides, several investigators utilized nude mice models to assess the chemopreventive efficacy of $\alpha$-MG. The studies were mostly performed in nude mice ectopic xenograft models, where $\alpha$-MG exhibited significant inhibitory effects against the growth of (i) human colorectal adenocarcinoma HCT116 and HT-29 cells through the induction of apoptosis and inhibition of angiogenesis $[19,20]$, (ii) prostate cancer $22 \mathrm{Rv} 1$ cells through arresting cell cycle [21], (iii) human hepatoma SK-Hep-1 cells and tongue mucoepidermoid carcinoma YD-15 cells through the induction of apoptosis [22,23], and (iv) glioblastoma GBM8401 cells through the induction of autophagic death [24]. In addition, for pancreatic cancer, $\alpha$-MG not only markedly inhibited pancreatic cancer ASPC1 cell-derived ectopic xenograft tumors [25,26], but also PL-45 cell-derived orthotopic xenograft tumors [25], which can better maintain the original biological characteristics of tumor cells and have a relatively higher clinical relevance. Importantly, besides the inhibitory effects on the growth of primary tumors, $\alpha$-MG has also shown significant antimetastatic effects in animal models. Shibata et al. [27] successfully developed a metastatic cancer model by implanting murine mammary adenocarcinoma BJMC3879luc2 cells into syngeneic BALB/C mice, which induces a metastatic spectrum similar to that seen in human breast cancer. Using this model, they confirmed that $\alpha$-MG significantly attenuated the growth of tumors and the multiplicity of lymph node metastasis. Given that lymph node involvement is the most important prognostic factor in breast cancer patients, the antimetastatic activity of $\alpha$-MG detected in such a model may be of great significance in future clinical applications. However, the underlying mechanism remains unclear. It is well known that most solid tumors rely on angiogenesis to support their localized growth and metastatic dissemination, and the vascular density of a tumor is closely associated with its metastatic potential. Hence, the reduction of microvessel density and suppression of tumor angiogenesis by $\alpha$-MG in this context may partially explain its suppressive effects on metastasis. Certainly, before a definite impact of $\alpha$-MG in this regard can be ascertained, deeper investigations will be required.

\section{Mangostin as a Blocking Agent: Blocking Cancer Initiation}

Cancer initiation occurs as a consequence of rapid and irreversible attacks to cells. The attack may be due to the initial exposure to or uptake of a carcinogen and the subsequent stable genotoxic damage caused by its metabolic activation [28]. Other major causes include oxidative stress [29] and chronic inflammation [30]. The following section will discuss how $\alpha$-MG protects cells from the damage induced by metabolically activated carcinogens, oxidative stress, or chronic inflammation, thereby obstructing the initiation of carcinogenesis.

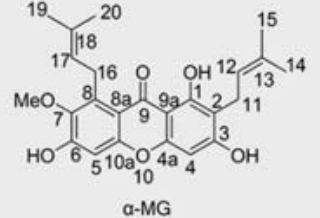

Fig. 1 Chemical structure of $\alpha$-MG.

\section{Modulation of phase I and phase II enzymes}

Many chemical carcinogens are metabolized by a process termed biotransformation. This process includes oxidative metabolism by phase I enzymes, especially those that belong to the cytochrome P450 (CYP) superfamily, and conjugation with polar groups by a series of phase II enzymes [e.g., glutathione-S-transferase, UDPglucuronosyltransferase, sulfotransferase, $\mathrm{NAD}(\mathrm{P}) \mathrm{H}$ : quinone oxidoreductase]. However, in the absence of phase II enzymes, this process may result in the production of excessive amounts of ROS and other active substances that assault cellular DNA, and thus procarcinogens are converted into carcinogens. Chemopreventive strategies include the inhibition of phase I enzymes responsible for activating carcinogens and induction of phase II enzymes that conjugate these activated compounds with endogenous ligands, thus contributing to their elimination [31].

Jung et al. [32] reported that $\alpha$-MG reduced the insurgence of DMBA-induced preneoplastic lesions in an ex vivo mouse mammary organ culture assay. Given that DMBA bioactivation requires phase I enzymes CYP1A1, CYP1A2, and CYP1B1 [33], it was reasonable to speculate that $\alpha$-MG repressed the initiation of carcinogenesis partly due to its inhibiting phase I enzymes. CYP19 is another member of the CYP family, alternatively known as aromatase, which is a rate-limiting enzyme in the biosynthesis of estrogen. Using an enzyme-based microsomal aromatase inhibition assay, Balunas et al. [34] found that $\alpha$-MG inhibited aromatase in a dose-dependent manner. Since estrogen plays a vital role in the development and progression of hormone-responsive breast cancers, $\alpha$-MG's suppressive effect on CYP19/aromatase indicates its potential as a chemopreventive or a chemotherapeutic agent in mammary carcinogenesis. Importantly, it was reported that in a concentration- and time-dependent way, $\alpha$-MG treatment increased the protein level and activity of $\mathrm{HO}-1$, an important cytoprotective protein induced during the phase II response [35]. Currently, however, studies regarding the effects of $\alpha$-MG on phase I and II enzymes and the involved signaling pathways are limited, which warrant further investigations.

\section{Antioxidant activity}

ROS/RNS is generated by various endogenous and exogenous pathways, such as the mitochondrial respiratory chain, inflammatory processes, lipid peroxidation, UV irradiation, and environmental pollutants [36]. Under normal conditions, cells maintain ROS/RNS at proper levels by the antioxidant action of enzymatic antioxidants, such as SOD, CAT, and GPx, as well as nonenzymatic antioxidants, such as GSH and uric acid [37]. When this balance is 
- Table 1 Antitumor activity of $\alpha$-MG in animal models.

\begin{tabular}{|c|c|c|c|}
\hline Animal model & Used dosage & Mechanisms/effects & Reference \\
\hline $\begin{array}{l}\text { 1,2-DMH-induced colon cancer } \\
\text { in F344 rats }\end{array}$ & $\begin{array}{l}\text { Dietary administration of } 0.02 \% \text { or } \\
0.05 \% \text { crude } \alpha \text {-MG ( } 77.8 \%) \text { for } 5 \text { weeks }\end{array}$ & $\begin{array}{l}\text { Inhibition of induction and development } \\
\text { of ACF; decrease in DF and BCAC; lowering } \\
\text { PCAN in colon }\end{array}$ & [17] \\
\hline $\begin{array}{l}\text { AOM- and DSS-induced colon cancer } \\
\text { in CD1 mice }\end{array}$ & $\begin{array}{l}\text { Dietary administration of } 200 \text { or } \\
500 \text { ppm } \alpha \text {-MG for } 16 \text { weeks }\end{array}$ & $\begin{array}{l}\text { Decreased multiplicities of neoplasms; } \\
\text { decreased PCAN positive index in colon } \\
\text { tumor; increased caspase-3 positive index }\end{array}$ & [18] \\
\hline $\begin{array}{l}\text { Human colon cancer HCT116 cells } \\
\text { xenograft tumor in athymic NCR nu/nu } \\
\text { nude mice }\end{array}$ & $\begin{array}{l}\text { Dietary administration of } 0.25 \% \text { or } \\
0.5 \% \text { mangosteen pericarp extract } \\
(\alpha-\mathrm{MG} 81 \%) \text { for } 20 \text { days }\end{array}$ & $\begin{array}{l}\text { Inhibition of tumor growth via direct } \\
\text { cytotoxicity on the tumor cells and/or } \\
\text { reduction the number of intratumor } \\
\text { blood vessels }\end{array}$ & [19] \\
\hline $\begin{array}{l}\text { Human colon cancer HT-29 cells xeno- } \\
\text { graft tumor in BALB/c nu/nu mice }\end{array}$ & $\begin{array}{l}\text { Dietary administration of } 900 \mathrm{mg} / \mathrm{kg} \\
\alpha \text {-MG for the } 5 \text { weeks }\end{array}$ & $\begin{array}{l}\text { Reduction of tumor mass; decrease in } \\
\text { concentrations of } \mathrm{Bcl}-2 \text { and } \beta \text {-catenin in } \\
\text { tumors }\end{array}$ & {$[20]$} \\
\hline $\begin{array}{l}\text { Human prostate cancer } 22 R v 1 \text { cells } \\
\text { xenograft tumor in athymic nu/nu mice }\end{array}$ & $\begin{array}{l}\text { Oral gavage of } 100 \mathrm{mg} / \mathrm{kg} / \mathrm{BW} \alpha-\mathrm{MG} \\
\text { five times weekly }\end{array}$ & $\begin{array}{l}\text { Inhibition of tumor growth via targeting } \\
\text { cyclin D1 and CDK4 }\end{array}$ & [21] \\
\hline $\begin{array}{l}\text { Human hepatoma SK-Hep- } 1 \text { cells } \\
\text { xenograft tumor in immunodeficient } \\
\text { BALB/c male mice }\end{array}$ & $\begin{array}{l}\text { Intraperitoneal administration of } 8 \mathrm{mg} / \\
\mathrm{kg} / \mathrm{BW} \alpha \text {-MG daily for } 42 \text { days }\end{array}$ & $\begin{array}{l}\text { Inhibition of tumor growth; induction } \\
\text { of mitochondria apoptotic pathway via } \\
\text { inactivation of p } 38 \text { MAPK }\end{array}$ & {$[22]$} \\
\hline $\begin{array}{l}\text { Human tongue mucoepidermoid } \\
\text { carcinomanude YD-15 cells xenografts } \\
\text { tumor in nude mice }\end{array}$ & $\begin{array}{l}\text { Intraperitoneally administration of } \\
10 \text { or } 20 \mathrm{mg} / \mathrm{kg} / \mathrm{BW} \alpha \text {-GM five times } \\
\text { weekly for } 22 \text { days }\end{array}$ & $\begin{array}{l}\text { Decrease of tumor weight; decrease of Ki- } \\
67 \text { expression; induction of mitochondria } \\
\text { apoptotic pathway via inactivation of p } 38 \\
\text { MAPK and ERK } 1 / 2\end{array}$ & [23] \\
\hline $\begin{array}{l}\text { Human malignant glioblastoma } \\
\text { GBM8401 cells xenograft in nude Balb/ } \\
\text { CA-v }(v / v)\end{array}$ & $\begin{array}{l}\text { Intraperitoneal administration of } 2 \mathrm{mg} / \\
\mathrm{kg} / \mathrm{BW} \alpha \text {-MG daily for } 28 \text { days }\end{array}$ & $\begin{array}{l}\text { Inhibition of tumor growth via increasing } \\
\text { phosphorylation of AMPK and induction } \\
\text { of autophagy }\end{array}$ & {$[24]$} \\
\hline $\begin{array}{l}\text { Secondary human pancreatic cancer } \\
\text { ASPC1 cell-derived ectopic xenograft } \\
\text { tumors in nude mice }\end{array}$ & $\begin{array}{l}\text { Intraperitoneal administration of } 6 \mathrm{mg} / \\
\mathrm{kg} / \mathrm{BW} \alpha \text {-GM five times weekly for } 8 \\
\text { weeks }\end{array}$ & $\begin{array}{l}\text { Inhibition of Ki- } 67 \text { and PCNA in tumor } \\
\text { tissues }\end{array}$ & {$[25,26]$} \\
\hline $\begin{array}{l}\text { Primary human pancreatic cancer } \\
\text { PL- } 45 \text { cell-derived orthotopic xenograft } \\
\text { tumors in nude mice }\end{array}$ & $\begin{array}{l}\text { Intraperitoneal administration of } 6 \mathrm{mg} / \\
\mathrm{kg} / \mathrm{BW} \alpha \text {-GM five times weekly for } 8 \\
\text { weeks }\end{array}$ & $\begin{array}{l}\text { Inhibition of Ki- } 67 \text { and PCNA in tumor } \\
\text { tissues }\end{array}$ & {$[25]$} \\
\hline $\begin{array}{l}\text { Murine mammary adenocarcinoma } \\
\text { BJMC3879luc } 2 \text { xenograft tumor in } \\
\text { syngeneic BALB/c mice }\end{array}$ & $\begin{array}{l}10 \text { or } 20 \mathrm{mg} / \mathrm{kg} / \mathrm{BW} \alpha \text {-GM daily via the } \\
\text { mini-osmotic pumps for six weeks }\end{array}$ & $\begin{array}{l}\text { Suppression of tumor growth and lymph } \\
\text { node metastasis via apoptotic cell death, } \\
\text { reduction of phospho-Akt, and micro- } \\
\text { vessel density }\end{array}$ & {$[26]$} \\
\hline
\end{tabular}

disturbed, cellular defenses can be overwhelmed, and the cell is injured by oxidative modifications of proteins and carbohydrates, DNA strand nicks, and lipid peroxidation. It has been proven that $\alpha$-MG possesses protective effects in models where oxidative stress and antioxidant deficit are major players, such as rats with isoproterenol-induced myocardial infarction [38,39], Langendorff-reperfused hearts [40], and rat brain tissues exposed to different toxic insults [41]. The underlying mechanisms include (i) direct free radical scavenging, (ii) modulation of oxidative stressrelated enzymes, and (iii) attenuation of inflammation.

$\alpha$-MG was firstly proven to have antioxidant activity using the ferric thiocyanate method $[42,43]$. Thereafter, Williams et al. [44] found that $\alpha$-MG served as a free radical scavenger to inhibit LDL oxidation induced by copper or peroxyl radical. Consistently, Mahabusarakam et al. [45] reported that $\alpha-\mathrm{MG}$ and its synthetic derivatives inhibited the decrease of $\alpha$-tocopherol consumption in copper-induced LDL oxidation, and the structural modifications of $\alpha$-MG differently affected the antioxidant activity: (i) substitution of C-3 and C- 6 hydroxyl groups with aminoethyl increased the activity, and (ii) substitution of C-3 and C-6 hydroxyl groups with methyl, acetate, propanediol, or nitrile reduced the activity. There is substantial evidence supporting the capacity of $\alpha$-MG to scavenge superoxide anion $\left(\mathrm{O}_{2}^{-*}\right)$, hydroxyl radicals $(\mathrm{OH} \cdot)$, and $\mathrm{H}_{2} \mathrm{O}_{2}$ [46-49]. On the other hand, $\alpha$-MG was shown to possess peroxynitrite $\left(\mathrm{ONOO}^{-}\right)$scavenging activity using authentic and 3-morpholinosydnonimine-derived peroxynitrite methods [32, 46]. Moreover, studies carried out in several cell/tissue models have confirmed the effectiveness of $\alpha$-MG in counteracting lipoperoxidation and oxidative stress-mediated damage by its ability of quenching free radicals. For example, in cultured Chinese hamster lung cells exposed to paraquat $\left(\mathrm{a} \mathrm{O}_{2}^{-\bullet}\right.$ generator) and $\mathrm{NaNO}_{2}$, $\alpha$-MG treatment demonstrated potent antigenotoxic effects [50]. Also, it has been found that in brain tissue exposed to different toxic insults, $\alpha$-MG exerts a robust antiperoxidative effect [41]. However, such activity could lead to the formation of semiquinone radicals and quinones. For the sake of security, it has to be taken into account that a high concentration of $\alpha$-MG might exert prooxidant activities, potentially favoring toxic effects and tissue dam- 
ages. Indeed, this compound was observed to protect mitochondria from peroxidative damage, but at a high concentration, it disrupted the mitochondrial energy metabolism and made it prone to permeability transition by triggering oxidative stress [51].

Intervention with the cause of oxidative stress by inhibiting enzymes that generate ROS is another approach of antioxidant strategy. aSMase, a member of sphingolipid catabolic enzymes, catalyzes the breakdown of sphingomyelin to generate ceramide [52]. Accumulating evidence demonstrated that aSMase activation and ceramide production are upstream signals of ROS, which trigger the activation of ROS-generating enzymes, including NADPH oxidase, xanthine oxidase, NO synthase, and the mitochondrial respiratory chain [53-55]. Therefore, the inhibition of aSMase activity and ceramide production might be an effective strategy to disturb the production of ROS. In a study by Okudaira et al. [56], $\alpha$-MG was identified to effectively inhibit the activity of aSMase derived from bovine brain and the production of ceramide, suggesting its potential in hampering the process of ROS production. Recently, our research group is devoted to searching for effective aSMase inhibitors. We have firstly constructed 3D-pharmacophore based on ligands and acquired a great array of mangostin derivatives, some of which were comparable to or more potent than $\alpha$-MG [57]. Besides inhibiting ROS-generating enzymes, $\alpha$-MG also exerted potential in the modulation of antioxidant enzymes. For example, in rat brain synaptosomes exposed to 3-nitropropionic acid, $\alpha$-MG increased GPx activity and transiently depleted GSH levels [58]. Pretreatment with $\alpha$-MG to rats diminished the decrease of SOD, CAT, and GPx in isoproterenol-induced myocardial infarction, rendering them to recover to normal levels, and concomitantly decreased lipid peroxidation levels [38].

A sustained production of ROS/RNS contributes to the pathological consequences of chronic inflammation. Activated inflammatory cells (e.g., neutrophils, monocytes, and macrophages), in turn, give rise to a variety of ROS/RNS (e.g., $\mathrm{O}_{2}^{-\bullet}, \mathrm{NO}, \mathrm{ONOO}^{-}$, and $. \mathrm{OH})$, leading to various genetic/epigenetic changes triggering the initiation of carcinogenesis $[59,60]$. iNOS is well known to be implicated in the excessive production of NO in response to immunological or inflammatory stimuli. In RAW 264.7 macrophages activated with LPS, $\alpha$-MG remarkably reduced the levels of iNOS expression and NO production, indicating that it possesses antiinflammatory and antitumorigenic potential [61,62]. COX-2 is the rate-limiting enzyme in the conversion of arachidonic acid to prostaglandins. It is induced in many types of cells by inflammatory mediators and various stimuli (e.g., oncogenes, mitogens, tumor promoters, and growth factors). COX-2-dependent reactions can generate ROS during the conversion of arachidonic acid to prostaglandin G2, causing direct oxidative damage to DNA [63]. Moreover, the products prostaglandins are thought to be a causative factor of cellular injury and may ultimately result in carcinogenesis. In breast cancer MDA-MB-231 cells treated with $\alpha$-MG and stimulated with LPS, the induction of COX-2 was markedly attenuated in a dose-dependent manner both at the transcriptional and translational levels [64]. Besides, Navya et al. [65] investigated the molecular interaction mechanisms of $\alpha$-MG with the two enzymes iNOS and COX-2 by utilizing computer docking tools. The results suggested that $\alpha$-MG was a ligand against COX2 and iNOS, respectively, and bound with them through the hy- drogen bond interaction. Further experimental tests are required to determine whether this compound can directly act on COX-2 and iNOS or not. As a mechanism upstream to iNOS and COX-2 inhibition, $\alpha$-MG was shown to activate SIRT-1, a nicotinamide adenosine dinucleotide-dependent histone deacetylase. SIRT-1 physically interacts with the p65/RelA subunit of NF- $k B$ and suppresses NF- $\kappa$ B-driven gene transcription by deacetylating p65/RelA at lysine 310 [66]. The overproduction of ROS inhibits SIRT-1 activity by initiating oxidative modifications on its cysteine residues, thereby enhancing NF- $\kappa$ B signaling resulting in inflammatory responses. As reported in a recent study, $\alpha$-MG was observed to abrogate the acetylation of $p 65 / N F-\kappa B$ and NF- $\kappa B$-regulated proinflammatory gene expressions, including COX-2 and iNOS, by activating SIRT-1 in the U937 cell line [67].

\section{Mangostin as a Suppressing Agent: Suppressing Cancer Promotion and Progression}

In the cancer promotion phase, cells with a dysfunction of key cellular proliferation control and apoptosis regulatory proteins persist, actively replicate, and accumulate to originate a focus of preneoplastic cells. Subsequently, the preneoplastic cells transform into neoplastic ones with the acquisition of angiogenic properties as well as invasive and metastatic potential, entering into the stage of cancer progression. Therefore, the strategies that can induce cell cycle arrest and/or apoptosis, disrupt angiogenesis, or prevent tumor cells escaping from the original location and invading other tissues could be beneficial for cancer prevention [68]. $\alpha$-MG has been shown to have antiproliferative, proapoptotic, antiangiogenic and antimetastatic activities against a wide range of cancer cell types by modulating various aberrant molecules and signal transduction pathways.

\section{Induction of cell cycle arrest}

Defects in cell cycle regulation are major causes of the abnormal proliferation of cancer cells, among which the deregulation of the $\mathrm{G} 1 / \mathrm{S}$ transition is especially common in human cancers $[69,70]$. $\alpha$-MG has been shown to modulate the major cell cycle mediators at micromolar concentrations, causing a blockage of the $\mathrm{G} 1 / \mathrm{S}$ transition, resulting in a G1-phase cell cycle arrest in many cancers, such as prostate cancer [71], melanoma [72], breast cancer [73], and pancreatic cancer [74]. Its antiproliferative activity involved the downregulation of cell cycle-related molecules CDKs $4 / 6$, cyclins D1/D3/E, and hyperphosphorylated Rb, and the induction of cyclin-dependent kinase inhibitors p53, p21, and p27. For example, Johnson et al. [71] demonstrated that $\alpha$-MG effectively blocked the $\mathrm{G} 1$ phase progression by upregulating the protein expression of p27KIP1 and downregulating that of cyclins D1 and D3, phosphorylated Rb, and cyclin $\mathrm{E}$ in human prostate cancer $22 R v 1$ cells. In this study, the investigators also found that $\alpha$ MG could directly inhibit the activity of CDK4 as shown in a cellfree biochemical kinase assay, and generated hypothetical binding arrangements between CDK4 and $\alpha$-MG by employing molecular modeling. It is tempting to speculate that this compound is 
able to fit within the deep and narrow ATP binding pocket of CDK4 due to its planar structure and hydrophobic isoprenyl groups along with neighboring hydrogen-bonding donors at C-1 and $\mathrm{C}-3$. The tumor suppressor p53 mainly induces p21 under stress conditions in order to maintain the balance between cell growth and death in living systems, however, this "gatekeeper" is often inactivated by mutations that lead to unlimited cellular proliferation in various cancers [75]. Interestingly, in cells lacking wild-type p53, $\alpha$-MG could still induce the expression of p21 and subsequent $\mathrm{G} 1$ phase arrest in a p53-independent pathway [72,73]. In another interesting study, $\alpha-\mathrm{MG}$ was found to inhibit the proliferation of colon cancer HCT116 cells in a p53-dependent manner, but the expression of p21CIP1 was proven unnecessary [76]. The investigators examined the underlying mechanism and provided evidence for the first time that $\alpha$-MG arrested cells in the G1 phase by the induction of another tumor suppressor p16INK4A via activation of the p38 MAPK stress kinase pathway and consequent downregulation of Bmi-1. p16INK4A is commonly inactivated in cancer cells under the repressive effects of oncoprotein Bim-1. Activation of the p38 MAPK signaling pathway can lead to the phosphorylation and protein degradation of Bim-1, thereby terminating its negative effect on p16INK4A and restoring the p16INK4A-induced growth inhibition and cell cycle arrest [77]. This work provides new insights into the molecular basis of $\alpha$ MG's antiproliferative activity outside its role in the p53-p21axis. In other cancer cells, $\alpha$-MG was reported to arrest the cell cycle at the $S$ phase [78], G0/G1 phase [25, 79], or G2/M phase [80]. In addition, $\alpha$-MG's antiproliferative activity might also be ascribed to its direct inhibition of DNA synthesis by diminishing DNA polymerases and topoisomerases. Dating back to 1997, $\alpha$-MG was firstly found to exhibit inhibitory effects on DNA topoisomerases I and II. A recent study by Mizushina et al. [80] reported on its potent effects on both polymerases and topoisomerases. Moreover, $\alpha$-MG treatment afforded a significant inhibition against topoisomerases, halting the cell cycle at the G2/M phase in HCT116 cells. Also, this study suggested that $\alpha$-MG did not bind to double-stranded DNA acting as a DNA intercalating agent or as a template-primer substrate, but rather that this compound directly bound with the enzyme and inhibited its activity, as shown by the thermal transition analysis. In contrast, the classical inhibitors directly bind to DNA and subsequently indirectly suppress the activity of topoisomerase. Hence, $\alpha$-MG might be a new type of topoisomerase inhibitor.

\section{Induction of apoptosis}

Apoptosis plays a critical role in eliminating the mutated and hyperproliferative neoplastic cells from the organism, and is therefore regarded as a major protective mechanism against the development of cancer. $\alpha$-MG has been reported to induce apoptosis of various cancer cells in culture and implanted tumors in animal models via modulation of multiple proapoptotic and antiapoptotic signaling molecules $[81,82]$. Importantly, it can selectively target cancer cells while having little influence on normal cells, indicating its potential in circumventing conventional chemotherapeutant-induced toxicity [83-85].

In general, there are two major apoptotic pathways: the extrinsic or death receptor pathway and the intrinsic or mitochondrial pathway. The extrinsic pathway is induced through the binding of death ligands with death receptors on the cell surface leading to the activation of caspase-8. The intrinsic pathway is characterized by the loss of mitochondrial membrane potential, leading to the release of cytochrome $c$ and caspase-9 activation [86]. Many studies suggested that $\alpha$-MG induced apoptosis through both the extrinsic and intrinsic pathways as shown by the activation of caspases-8, -9 and -3 , such as human hepatoma SK-Hep-1 cells [22], melanoma SK-MEL-28 cells [72], and breast cancer MDAMB-231 cells [78]. Interestingly, Watanapokasin et al. [87] observed the upregulation of Fas and tBid occurring in human colorectal cancer COLO 205 cells. The proposed mechanism for $\alpha$-MG-induced apoptosis was that upon $\alpha$-MG treatment, the extrinsic pathway was activated, procaspase- 8 was cleaved to caspase- 8 , and then further activated the cleavage of Bid to tBid; the $\mathrm{tBid}$ then translocated to mitochondria resulting in the activation of the mitochondrial apoptotic pathway [87]. The depletion of mitochondrial membrane potential, decrease in intracellular ATP, downregulation of proapoptotic $\mathrm{Bcl}-2$ and upregulation of antiapoptotic Bax, release of cytochrome c from mitochondria into cytosol, activation of the caspase cascade, and enhancement of PARP cleavage were the main events involved in the mitochondrial apoptotic pathway induced by $\alpha$-MG $[23,88]$. However, this was not in agreement with the findings of Matsumoto et al. [89] who reported that $\alpha$-MG directly targeted mitochondria and induced apoptosis as evidenced by the activation of caspases- 9 and -3 , but not caspase-8. This obvious conflict in the data may be because this compound exerted its activity by different pathways in different types of cancer cells. Caspases are common to both the extrinsic and intrinsic pathways, however, $\alpha$-MG induced caspaseindependent mitochondrial apoptosis with the release of a caspase-independent apoptogenic factor endonuclease- $G$ from mitochondria in human colorectal cancer DLD-1 cells. Interestingly, this study also suggested that the miR-143/ERK5/c-Myc pathway was involved in $\alpha$-MG-induced apoptosis [90].

$\alpha$-MG induced apoptosis in various cancer cells is in a cell-typespecific manner, being p53-dependent in certain cells, while p53independent in others. In human colorectal carcinoma HCT 116 cells, $\alpha$-MG induced apoptosis by increasing p53 transcriptional activity followed by activating the ERK pathway [19]. Increased levels of $\mathrm{p} 53$ and $\mathrm{Bax}$, and decreased $\mathrm{Bcl}-2$ were detected in various head and neck squamous carcinoma cell lines when exposed to $\alpha$-MG [91]. In addition, $\alpha$-MG had the capability to inhibit the negative effect of MDM2 on p53, as a potential inhibitor of the p53-MDM2 interaction, restoring the p53-induced growth inhibition in breast cancer cell MCF-7 (with wt p53 and overexpression of MDM2). This finding provides a new perspective into the mechanism of action of $\alpha-\mathrm{MG}$ in human cancer cells with wt p53 [92]. However, the $\alpha$-MG-induced apoptotic pathway in breast cancer BJMC3879luc2 cells harboring a p53 mutation emerged through a p53-independent mechanism [93].

$\alpha$-MG-treated MCF-7 cells displayed dose- and time-dependent downregulation of estrogen receptor $\alpha$, along with the reduced expression of the estrogen-responsive pS2 gene, suggesting its apoptotic effect in estrogen receptor-positive breast cancer was at least partly mediated through an estrogen receptor-related pathway [94]. $\alpha$-MG has been reported to decrease cell viability 
and inhibit clonogenic survival through induction of autophagy, but not apoptosis, in glioblastoma GBM8401 cells by activation of the LKB1/AMPK pathway and subsequent inactivation of mTORC1 [24]. In chronic myeloid leukemia cell lines, inhibition of autophagy enhanced the $\alpha$-MG-mediated cytotoxicity through promoting apoptosis [84]. This was not surprising because autophagy has been well characterized to play the Janus role, promoting tumor cell survival in the presence of certain stresses on one hand, but inhibiting the tumor cell growth on the other hand [95]. Recently, ER stress has been regarded as the third apoptotic pathway. $\alpha$-MG was found to selectively promote ER stress so as to increase the apoptotic indices of prostate cancer cells, while exerting little influence on normal prostate epithelial cells $[96,97]$.

\section{Suppression of angiogenesis}

Abnormal angiogenesis is necessary for tumor growth and metastasis. Thus, effective inhibition of angiogenesis may provide a crucial strategy for halting the process of carcinogenesis. It is well known that most solid tumors induce vascular proliferation by producing angiogenic factors, prominently VEGF [98]. VEGF can stimulate endothelial cell proliferation, migration, and subsequent differentiation to form new vessels. It exerts its angiogenic properties by binding with VEGFR (mainly VEGFR2), which is found at the surface of endothelial cells. This binding causes conformational changes of the receptors, followed by dimerization and autophosphorylation of the tyrosine residues, thereby activating downstream signaling, such as MAPK and PI3K/Akt pathways [99]. $\alpha$-MG has been shown to reduce the expression of VEGF in T47D breast cancer cells in vitro [100] and pancreatic cancer ASPC1 cells-derived xenograft tumors in nude mice [26]. Hypoxia-activated secretion of VEGF-A and SDF-1, which are associated with angiogenesis and chemoattraction of cancer cells and endothelial cells, was abolished by $\alpha$-MG [101]. In addition, $\alpha$-MG inhibited VEGF-mediated biological effects by interfering with VEGF signaling pathways. Jittiporn et al. [102] found that $\alpha$-MG dramatically and dose dependently suppressed VEGF-induced hyperpermeability, increased proliferation, migration, and tube formation in retinal endothelial cells, and limited vascular sprouting in the ex vivo aortic ring assay through suppressing VEGF-induced phosphorylation of VEGFR2 and ERK1/2 (a major downstream target of VEGFR2). Another study reported on its inhibitory effects on VEGF-induced proliferation, migration, and tubule formation of human umbilical vein endothelial cells [103]. This study also examined site-specific phosphorylation of VEGFR2 and revealed that $\alpha$-MG inhibited ATP-induced phosphorylation of recombinant VEGFR2 at the Y1175. Taking these results together, it can be concluded that $\alpha$-MG possesses dual roles, the decrease of the VEGF secretion from tumor cells and the direct action on endothelial cells. Such dual activities of $\alpha$-MG, different from the single effect of other angiogenesis inhibitors, should rationally make $\alpha$-MG elicit better antiangiogenic activity.

\section{Inhibition of migration, invasion metastasis}

The invasion of tumor cells through tumor-associated stroma and subsequent metastasis are the central events in neoplastic progression [104]. Excessive degradation of extracellular matrix mediated by proteolytic enzymes such as activated MMPs, especially
MMP-2 and MMP-9, is one of the hallmarks of tumor invasion and migration. $\alpha$-MG could downregulate the expressions of MMP-2 and MMP-9 in a concentration-dependent manner, thereby blocking the invasion and metastasis of various cancers, including skin cancer [105], head and neck squamous cell carcinoma [106], lung adenocarcinoma [107], prostate carcinoma [108], and pancreatic cancer [109]. The underlying mechanisms were closely associated with the suppression of upstream kinase(s), such as MAPK family members (ERK, JNK, and p38) and PI3K/Akt, and the inactivation of downstream transcription factor(s), such as NF-KB and AP-1. In addition, the study performed in PMA-treated highly metastatic human lung adenocarcinoma A549 cells further explored the upstream regulators, a new finding from which ERK $1 / 2$ inhibition and NF- $\kappa$ B inactivation emerged through impeding the activation of $\alpha v \beta 3$ integrin and phosphorylation of FAK [107]. TIMPs occur naturally within the extracellular matrix, which inhibit both proand active MMPs and provide a homeostatic environment in the matrix. The anti-invasive potential of $\alpha$-MG against various pancreatic cancer cell lines was partly ascribed to the upregulation of TIMP1 and subsequent inhibition of MMP9 [25].

EMT is the process wherein epithelial cells acquire fibroblastlike properties and show decreased cell-cell adhesion and enhanced motility. Its occurrence during tumor progression was proven to be a major mechanism responsible for the invasiveness and metastasis of cancer cells. $\alpha$-MG was found to block EMT progression of pancreatic cancer BxPc-3 and Panc- 1 cells, as evidenced by the upregulation of epithelial marker E-cadherin and the downregulation of mesenchymal markers vimentin and $\mathrm{N}$ cadherin in the control of the PI3K/Akt signaling pathway [73]. The action of inhibiting EMT progression further identified its inhibitory capacity on dissemination and invasion. Recent advances indicate that the tumor microenvironment plays a key role in tumor progression and invasion. A recent study conducted by Lei et al. [101] reported that PSCs and hypoxia exhibited a synergistic effect on accelerating pancreatic cancer EMT and invasion. Interestingly, $\alpha$-MG had a protective effect against hypoxia in the pancreatic tumor-stromal interaction, including abolishing hypoxiadriven PSC activation, inhibiting EMT, and blocking cancer cell invasion, which was associated with its ability to inhibit hypoxiainduced ROS production as well as HIF- $1 \alpha$ stabilization and GLI1 expression.

\section{Cytotoxic activity in combination with clinical chemotherapeutic drugs}

Phytochemicals can synergize with classical chemotherapeutic drugs, increasing their efficacy and lowering the toxic side effects on normal cells, including $\alpha$-MG. For example, $\alpha-M G$ exhibited a synergistic effect on 5-FU-induced growth inhibition of human colon cancer DLD-1 cells at lower concentrations $(<5 \mu \mathrm{M})$, decreasing the clinical dose of 5-FU, thereby lowering the systemic toxicity of 5-FU and increasing its therapeutic index [89]. $\alpha$-MG protected renal epithelial cells from cisplatin-induced apoptosis via inhibition of p53 induction and ROS generation. On the other hand, it attenuated oxidative/nitrosative stress as well as inflammatory and fibrotic markers, offering renoprotective effects against cisplatin-induced injury in rats $[110,111]$. In addition, $\alpha$ MG possessed protective effects against doxorubicin-induced 
neurotoxicity by ameliorating oxidative damage and regulating proapoptotic and antiapoptotic proteins [112].

\section{Inhibition of survival pathways}

The following section will summarize studies that investigated the effects of $\alpha$-MG on survival pathways. Activation of the MAPK (JNK, ERK1/2, and p38) or Akt signaling pathway is involved in a variety of oncogenic processes, including cell proliferation, antiapoptotic cell death, angiogenesis, and metastasis [113,114]. Several studies have reported that $\alpha$-MG inhibited the MAPK or $\mathrm{PI} 3 \mathrm{~K} /$ Akt pathway, thereby exerting its inhibition of cell growth and induction of apoptosis in cancer cells [115]. For example, $\alpha$ MG induced mitochondria-mediated apoptosis of YD-15 tongue carcinoma cells through inhibiting phosphorylation of ERK1/2 and p38 MAPK in a dose-dependent manner [23]. Phosphorylated and total ERK, JNK, and Akt were downregulated in $\alpha$-MG-treated SW1353 cells, but there were no changes in p38 MAPK [88]. In both mammary carcinoma cells in culture and tissues in vivo, $\alpha$ MG significantly decreased the levels of phospho-Akt-Thr308 [27]. In addition, there is substantial evidence that $\alpha$-MG restrained the process of invasion and migration in cancer cells by acting on the MAPK or Akt pathway. Indeed, $\alpha$-MG could mediate the metastasis of human prostate cancer PC-3 cells through reducing the expression of MMP-2/9 and u-PA via the suppression of the JNK1/2 signaling pathway and inhibition of NF-KB and AP-1 DNA binding activity [108]. In pancreatic cancer cell lines MIAPaCa-2 and BxPC-3, $\alpha$-MG suppressed LPS-induced invasion and metastasis by inhibiting MMP-2/9 expression and increasing E-cadherin through inactivating the ERK signaling pathway [109].

Signaling pathways mediated via upstream kinases converge on divergent classes of transcription factors, such as NF- $\kappa B$ and STAT3 [116]. Aberrant and sustained activated NF- $K B$ has been implicated in various stages of tumorigenesis and is found in a number of cancers. A number of natural chemopreventive agents have been reported to be potent inhibitors of NF- $K B$, including $\alpha$-MG. The carcinogens like PMA and TPA, as well as inflammatory agents like LPS and TNF- $\alpha$ are potent activators of NF- $k$ B, and $\alpha$ MG could inhibit the activation of NF- $k B$ induced by these agents in a dose-dependent manner. In fact, $\alpha$-MG not only suppressed the inducible form of NF- $\kappa \mathrm{B}$, but also inhibited constitutively activated NF- $\kappa B[78,80]$. It interfered with the canonical NF- $K B$ signaling pathway by downregulating the expression of p65/NF-KB, IKKy (NEMO), and IKK $\beta$ in pancreatic cancer cells, which is partly responsible for its capabilities of growth inhibition and apoptosis induction [25]. Besides influencing tumor cell proliferation and survival, NF-kB also promotes invasion, metastasis, and angiogenesis. Many studies have revealed $\alpha$-MG's inhibitory activities against invasion and migration of cancer cells, and the inhibition of NF- $K B$ is one of the most important mechanisms for its antimetastatic effects. For example, $\alpha$-MG exhibited a significant antimetastatic effect against TPA-stimulated human breast cancer MCF-7 cells through the inhibition of nuclear translocation and DNA binding activity of NF- $\kappa$ B via blocking phosphorylation and degradation of $I_{\kappa} B \alpha[117]$. It has been reported that functions mediated by NF- $\kappa$ B are at least partially performed in cooperation with STAT3. Actually, besides inhibiting the NF- $\kappa$ B pathway, $\alpha$-MG exposed to pancreatic cancer cells inhibited the constitutive expression of
STAT3 proteins and its phosphorylation [80]. Shan et al. [118] observed that $\alpha$-MG inhibited proliferation and promoted apoptosis of gastric adenocarcinoma BGC-823 and SGC-7901 cells, possibly by suppressing the activation of STAT3 and the expression of its regulated genes, including $\mathrm{BCl}-\mathrm{xL}$ and $\mathrm{Mcl}-1$. The overview of all the aberrant molecules and signaling pathways modulated by $\alpha$-MG is shown in $>$ Table 2.

\section{Toxicity and Pharmacokinetic Studies}

As mentioned above, an impressive number of studies demonstrate that $\alpha$-MG possesses chemopreventive and therapeutic potential in cancer. In order to successfully translate such promising observations from the preclinical to clinical stage, studies on its toxicological profile as well as pharmacokinetics and bioavailability are mandatory. Within the past years, several research groups have evaluated the potential in vivo toxicity of $\alpha$-MG (pure compound or as a constituent of mangosteen fruit extract) primarily in rodents. Ibrahimet et al. [119] firstly performed a complete in vivo toxicological evaluation of $\alpha$-MG. Oral gavage with $\alpha$-MG at a single dose as high as 1000 mg/kg BW (acute toxicity) did not produce any toxicity in ICR mice regardless of gender, as demonstrated by no occurrence of treatment-related adverse effects on BW, organ weight, serum biochemistry, histopathology, and oxidative stress biomarkers. Jujun et al. [120] reported that the ethanol extracts of mangosteen administrated orally to rats at a highest single oral dose of $5000 \mathrm{mg} / \mathrm{kg}$ BW (acute toxicity) and a highest daily dose of $1000 \mathrm{mg} / \mathrm{kg}$ BW for 28 days did not trigger any significant dose-related systemic toxicity as well as hematologic and histopathologic changes. Consistently, another study performed in mice by Bunyong et al. [121] also did not find any evidence of toxicity of mangosteen extracts at a single oral dose of $5000 \mathrm{mg} /$ $\mathrm{kg}$ BW (acute toxicity) and daily dose of $2000 \mathrm{mg} / \mathrm{kg}$ BW for 14 days (subacute toxicity). Hutadilok-Towatana et al. [122] demonstrated that hydroethanolic rind extracts of mangosteen administered orally to rats daily as high as $1200 \mathrm{mg} / \mathrm{kg}$ BW for 12 weeks (subchronic toxicity) did not cause any changes of general behavior and physiological status throughout the study period. After 12 weeks, no significant dose-related hematologic changes were observed among the female groups, although a dose variation increase of direct bilirubin was detected in all male groups. Moreover, neither gross necropsy nor histopathological examination of vital organs revealed any abnormalities regardless of gender. However, Gutierrez-Orozco et al. $[123,124]$ recently reported that dietary $\alpha$-MG at a dose of $112 \mathrm{mg} / \mathrm{kg}$ BW exacerbated DSS-induced injury and promoted microbial dysbiosis independent of mouse strain ( $\mathrm{C} 3 \mathrm{H}$, Balb/c, Nude FoxN1 ${ }^{\mathrm{nu}}$, and $\mathrm{C} 57 \mathrm{BL}$ ) 6] mice). It caused loss of BW, greater inflammatory and crypt injury scores, immune cell infiltration, ulceration, and an increased degree of hyperplasia and epithelial cell proliferation in the colon. Also, in a non-DSS-treated mice diet with $\alpha$-MG, epithelial cell proliferation and immune cell infiltration were also detected. This dose of $\alpha$-MG has been reported to be safe and effective in inhibiting or retarding the growth of implanted tumors in vivo without observed toxicity, as shown in other studies [21,22]. 
- Table 2 Molecular mechanisms behind the anticarcinogenic activities of $\alpha$-MG.

\section{Molecular mechanisms}

Modulation of phase I and II enzymes

Mammary tumorigenesis $\downarrow$, CYP1A1 $\downarrow$, CYP1A2 $\downarrow$, CYP1B1 $\downarrow$

CYP19/aromatase activity $\downarrow$

Protein expression and activity $\mathrm{HO}-1 \uparrow$

Antioxidant

aSMase activity $\downarrow$

Making SOD, GPx, CAT recover to normal level

Attenuation of inflammation

NO release $\downarrow$, PEG2 release $\downarrow$, iNOS expression $\downarrow$, COX-2 expression $\downarrow$

Protein and mRNA expressions of COX- $2 \downarrow$, PEG $2 \downarrow$

Direct interaction with COX-2 and iNOS

SIRT- $1 \uparrow$, p65/NFKB acetylation $\downarrow$, COX-2 expression $\downarrow$, iNOS expression $\downarrow$, NO production $\downarrow$, PEG2 level $\downarrow$

Induction of cell cycle arrest

cyclinD1/CDK4 expression $\downarrow$, p27KIP1 expression $\uparrow$, cyclinE expression $\downarrow$, phosphorylated Rb expression $\downarrow$ direct interaction with CDK4

G1-arrest, cyclin D1 expression $\downarrow$, p21WAF1expression $\uparrow$

G1-arrest, p21CIP1expression $\uparrow$, cyclins expression $\downarrow$, cdc(s) expression $\downarrow$, CDKs expression $\downarrow, P C N A \downarrow$, CHEK2 expression $\uparrow$

G1-arrest, cyclin-D1 expression $\downarrow$; G0/G1-arrest

G1-arrest, p16 INK4A $\uparrow$, p38MAPK $\downarrow$, Bmi-1 $\downarrow$; G2/M arrest, topoisomerases activity $\downarrow$

Direct interaction with topoisomerases

Induction of the apoptotic signaling pathway

Caspase-3 expression $\uparrow$, mitochondrial membrane potential $\downarrow$, cytochrome c expression $\uparrow$ Akt1/NF-kB expression $\downarrow$, Akt phosphorylation $\downarrow$

Mitochondrial membrane potential $\downarrow$, caspase-7, $-8,-9$ and-3 expression $\uparrow$, ROS $\uparrow$, Bcl-2 expression $\downarrow$, Bax expression $\uparrow$, Hsp70 protein expression $\downarrow$, NF-kB translocation $\downarrow$, PARP cleavage

Caspase-3,-9 expression $\uparrow$, mitochondrial membrane potential $\downarrow$, ROS $\uparrow$, ATP $\downarrow$, cytochrome c/AIF release

Mitochondrial membrane potential $\downarrow$ cytochrome c release, caspase-3, -8, -9 expression $\uparrow$, Bcl-2 expression $\downarrow$, Bax expression $\uparrow$, phospho-ERK, JNK, and Akt $\downarrow$

Mitochondrial membrane potential $\downarrow$, cytochrome $c$ release,caspase-3,-8,-9 expression $\uparrow$, tBid $\uparrow$, Bax expression $\uparrow$, p53 expression $\uparrow$, Bmf expression $\uparrow$, Fas expression $\uparrow$

Endonuclease-G release, microRNA-143 expression $\uparrow$, ERK5 expression $\downarrow$ phospho-Akt $\downarrow$, c-Myc $\downarrow$, phospho-Erk $1 / 2 \uparrow \downarrow$

Bcl-2 expression $\downarrow$, Bax expression $\uparrow$, p53 expression $\uparrow$

Caspases- 8 , -9 , and -7 expression $\uparrow$, cytochrome $c$ release, PARP cleavage, Bax expression $\uparrow$, p53 expression $\uparrow, \mathrm{Bcl}-2$ expression $\downarrow$, Bid $\downarrow$, ER $\alpha$ expression $\downarrow$

Inhibition of angiogenic and metastatic progression

VEGF expression $\downarrow$

VEGF-A/SDF- 1 secretion $\downarrow$

VEGFR $2 \downarrow$, EKR $1 / 2 \downarrow$

Phosphorylation of VEGFR2 $\downarrow$

MMP-2/MMP-9/NF-kB/Akt1 expression $\downarrow$

MMP-2/NF-kB expression $\downarrow$, IkB $\alpha$ expression $\uparrow$
Models

References

Ex vivo mouse mammary organ culture assay

Microsomal

Cerebellar granule neurons

Enzyme derived-bovine brain

Isoproterenol-induced myocardial infarction

LPS-stimulated RAW264.7 macrophage cells

$[61,62]$

Human breast cancer MDA-MB-231 cells

[64]

Molecular modeling and docking study

LPS-stimulated U937 cells

Human prostate cancer LNCaP cells and

22Rv1 cells

Human melanoma SK-MEL-28 cells

Human breast cancer MDA-MB-231 cells

$[74,79]$

Human pancreatic cancer BxPC3 and PANC

$[76,80]$

Human colon cancer HCT116 cells

Thermal transition analysis

Human melanoma SK-MEL-28 cells

Human breast cancer MDAMB-231 cell

Human leukemia HL60 cell

Human chondrosarcoma SW1353

[88]

cells

Human colon cancer COLO 205 cells

[89]

Human colon cancer DLD-1 cells

Head and neck squamous cell carcinoma $\mathrm{HN}-22, \mathrm{HN}-30$ and $\mathrm{HN}-31$ cells

[94]

Human breast cancer MCF-7 cell
Breast cancer T47D cells

[99]

Activated pancreatic stellate cells

Retinal microvascular endothelial cells

Human umbilical vein endothelial cells

[103]

Human melanoma SK-MEL-28 cells

Human squamous cell carcinoma A-431 cells
[106]

continued 
- Table 2 Continued

\begin{tabular}{|c|c|c|}
\hline Molecular mechanisms & Models & References \\
\hline $\begin{array}{l}\text { MMP-2/MMP-9 expression/activity } \downarrow \text {, } \alpha \vee \beta 3 \text { integrin } \downarrow \text {, FAK } \downarrow \text {, ERK1/2 } \downarrow \text {, IKB } \alpha \text { degration } \downarrow \text {, } \\
\text { NF-KB DNA binding } \downarrow\end{array}$ & Human lung adenocarcinoma A549 cells & [107] \\
\hline $\begin{array}{l}\text { MMP-2/MMP-9/u-PA expression } \downarrow \text {, JNK1/2 phosphorylation } \downarrow \text {, NF-KB/AP-1 binding } \\
\text { activity } \downarrow\end{array}$ & Human prostate carcinoma PC-3 cells & [108] \\
\hline MMP-2/MMP-9/E-cadherin expression $\downarrow$, ERK phosphorylation $\downarrow$ & $\begin{array}{l}\text { LPS-induced human pancreatic cancer } \\
\text { MIAPaCa- } 2 \text { and BxPC-3 cells }\end{array}$ & [109] \\
\hline $\begin{array}{l}\text { MMP-2/MMP-9/vimentin/N-cadherinexpression } \downarrow \text {, E-cadherin expression } \uparrow \text {, } \\
\text { Akt phosphorylation } \downarrow\end{array}$ & $\begin{array}{l}\text { Human pancreatic cancer BxPC- } 3 \text { and } \\
\text { Panc- } 1 \text { cells }\end{array}$ & [101] \\
\hline $\begin{array}{l}\text { MMP-2/MMP-9 expression } \downarrow \text {, ERK } 1 / 2 \downarrow \text {, IKB } \alpha \text { degradation } \downarrow \text {, nuclear levels of NF-KB/AP- } 1 \downarrow \text {, } \\
\text { NF-KB/AP-1 DNA binding } \downarrow\end{array}$ & TPA-induced human brest MCF-7 cells & [117] \\
\hline $\begin{array}{l}\text { pNF-kB/p65Ser552 } \downarrow, \text { pStat3Ser727 } \downarrow \text {, pStat3Tyr705 } \downarrow, \text { MMP9 } \downarrow \text {, DNA binding activity of } \\
\text { NF-kB/Stat3 } \downarrow, \text { TIMP1 expression } \uparrow\end{array}$ & $\begin{array}{l}\text { Human pancreatic cancer PL-45, PANC1, } \\
\text { BxPC3, and ASPC1 cells }\end{array}$ & {$[25]$} \\
\hline
\end{tabular}

The absorption, transport, metabolism, and excretion of $\alpha$-MG have also been investigated in several models: isolated intestinal microsomes, various human cell lines, and tissue homogenates as well as mice and rats. Using a digestion/Caco-2 human intestinal cell model, Bumrungpert et al. [125] demonstrated that (i) $\alpha$ MG was taken up by Caco-2 cells in a dose-dependent manner and partially converted into phase II metabolites, and (ii) both free and conjugated forms of $\alpha$-MG were transported across the basolateral membrane of Caco- 2 cells, suggesting that this compound and its phase II metabolites were absorbed and bioavailable. Subsequently, $\alpha$-MG was detected to be transported into various cell lines (macrophage-like THP-1, hepatic HepG2, enterocyte-like Caco-2, and colon HT-29), where it underwent phase II metabolism and biotransformation to get converted into other xanthones [126]. By in vitro metabolism studies using tissue homogenates, $\alpha$-MG was proven to be metabolized mainly via the liver and small intestine $[127,128]$. With regards to the formation of metabolites, the glucuronidated, bis-glucuronidated, dehydrogenated, hydrogenated, oxidized, and methylated $\alpha$-MG were tentatively identified [128]. In vivo animal studies showed that the majority of $\alpha$-MG occurred in the plasma as phase II metabolites and only minimal amounts as free forms after oral administration [129]. Phase II metabolites displayed a prolonged half-life compared to the free compound because they underwent enterohepatic recirculation and were reabsorbed from the bile to the intestine and back into the bloodstream again [129]. Recently, $\alpha$-MG was reported to have dose-independent (linear) pharmacokinetics at oral doses of $10-100 \mathrm{mg} / \mathrm{kg}$ BW in mice [128]. After oral administration, $\alpha$-MG $(10 \mathrm{mg} / \mathrm{kg})$ was detected in the plasma at the point of $5 \mathrm{~min}$, indicating a rapid gastrointestinal absorption, and was then assigned to most tissues except the brain; it was relatively high in the liver, intestine, kidney, fat, and lung [127, 128].

There has been some studies conducted to research the pharmacokinetics and safety of $\alpha$-MG in animal models, albeit with confusing, conflicting, and contradictory results. Similar studies on humans are limited to date. $>$ Table 3 summarizes the current knowledge on the clinical pharmacokinetic and safety studies about $\alpha$-MG-containing food products. In a randomized, double blinded, placebo-controlled study, ingestion of a blended mango- steen juice by healthy human subjects could decrease the serum CRP levels, however, other inflammation markers were increased compared to the placebo [130]. Qu and colleagues [131, 132] determined the bioavailability of the free form of $\alpha$-MG and vitamins B2 and B5 found in xanthone-rich mangosteen products (Verve ${ }^{\circledR}$ and Mangosteen Plus with Essential Minerals) and its efficacy on plasma antioxidant status in the human body. The results shown that $\alpha$-MG and vitamins B2 and B5 were bioavailable with an observed $C_{\max }$ at a $t_{\max }$ of around $1 \mathrm{~h}$, and the antioxidant capacity measured with the oxygen radical absorbance capacity assay was increased. Additionally, Chitchumroonchokchai et al. [133] revealed the presence of free and conjugated forms of $\alpha$-MG in plasma and urine after consuming a mangostin-rich mangosteen juice. In a recent randomized, double-blind, placebo-controlled clinical trial, the investigators examined the effects of a mangosteenbased beverage $\left(V^{2} r v e^{\circledR}\right.$ ) on antioxidant, anti-inflammatory, and immunity biomarkers in the plasma of healthy adults [134]. It was found that after the 30-day trial, the CRP level in the group given the mangosteen-based drink formula significantly decreased by $46 \%$, and that antioxidant capacity in the bloodstream showed $15 \%$ more than that in the placebo group. Immunity biomarkers $\operatorname{lgA}, \lg \mathrm{G}, \lg \mathrm{M}, \mathrm{C} 3$, and C4 were not affected in the mangosteen given group. Importantly, there were no side effects detected on hepatic and renal functions after long-term consumption.

The oral bioavailability of $\alpha$-MG, however, is very low, only $2.29 \%$ of oral $\alpha-M G$ at $10 \mathrm{mg} / \mathrm{kg}$ in mice [128], which is likely due to its intensive first-pass metabolism $[127,135]$ as well as poor absorption caused by low water solubility and the efflux effect of P-gp [136]. The low oral bioavailability has limited its further pharmacological exploitation. There have been some preliminary studies that attempted to improve its bioavailability. For instance, Fei et al. [137] synthesized several $\alpha-M G$ analogs through substitution of the hydroxyl groups at $\mathrm{C} 1, \mathrm{C} 3$, and C6, cyclization at C-2 and $\mathrm{C}-3$, and modification at $\mathrm{C} 4$ and at $\mathrm{C} 7$ with the aim of improving its antitumor activity and water solubility. Despite showing an improved water solubility, all of them reduced the activity of the parent compound. Aisha et al. [138] prepared solid dispersions of $\alpha$-MG in PVP that showed improved solubility, self-assembly of nanomicelles, and intracellular delivery through endocytosis, 
- Table 3 Clinical pharmacokinetic and safety studies of $\alpha$-GM containing products.

\begin{tabular}{|c|c|c|c|c|}
\hline Tested product & Delivery route & Dose & Observations & References \\
\hline $\begin{array}{l}\text { Mangosteen supplement } \\
\text { containing mangosteen juice, } \\
\text { vitamins, minerals, aloe vera, } \\
\text { and green tea }\end{array}$ & Oral & $\begin{array}{l}59 \mathrm{~mL} / \text { person/ } \\
\text { day for } 30 \text { days }\end{array}$ & $\begin{array}{l}\text { Decreased levels of serum CRP levels; in- } \\
\text { creased ratio of T helper to cytotoxic T cells; } \\
\text { increased serum levels of IL- } 1 \alpha \text { and IL- } 1 \beta \text {, and } \\
\text { complement components C } 3 \text { and C } 4\end{array}$ & [130] \\
\hline $\begin{array}{l}\text { Mangosteen beverage con- } \\
\text { taining mangosteen, aloe vera, } \\
\text { multivitamins, and green tea } \\
\left(\text { Verve }^{\circledR}\right)\end{array}$ & Oral & $\begin{array}{l}59 \mathrm{~mL} / \text { person } \\
\text { (single dose) }\end{array}$ & $\begin{array}{l}\mathrm{C}_{\max }, 3.12 \pm 1.47 \mathrm{ng} / \mathrm{mL} \text {, at } \mathrm{t}_{\max } \text { of } 1 \mathrm{~h} \text {; anti- } \\
\text { oxidant capacity increased with a maximum } \\
\text { effect of } 18 \% \text { after } 2 \mathrm{~h} \text {, and the increased } \\
\text { antioxidant level lasted at least } 4 \mathrm{~h}\end{array}$ & [131] \\
\hline $\begin{array}{l}\text { Mangosteen beverage con- } \\
\text { taining mangosteen, aloe vera, } \\
\text { multivitamins, and green tea } \\
\text { (Mangosteen Plus with Essen- } \\
\text { tial Minerals) }\end{array}$ & Oral & $\begin{array}{l}245 \mathrm{~mL} / \text { person } \\
\text { (single dose) }\end{array}$ & $\begin{array}{l}\mathrm{C}_{\max }, 4.16 \pm 2.85 \mathrm{ng} / \mathrm{mL} \text {, at } \mathrm{t}_{\max } \text { of } 1 \mathrm{~h} \text {; anti- } \\
\text { oxidant capacity increased with a maximum } \\
\text { effect of } 60 \% \text { after } 1 \mathrm{~h} \text {, and the increased } \\
\text { antioxidant level lasted at least } 6 \mathrm{~h}\end{array}$ & [132] \\
\hline $\begin{array}{l}100 \% \text { Mangosteen juice } \\
\text { containing } 58 \% \alpha \text {-GM }\end{array}$ & Oral & $\begin{array}{l}60 \mathrm{~mL} / \text { person } \\
\text { mangosteen juice } \\
\text { with a high-fat } \\
\text { breakfast }\end{array}$ & $\begin{array}{l}\text { Free and conjugated forms were detected in } \\
\text { serum and urine; } A U C, 762-4030 \mathrm{nmol} / \mathrm{L} \times \mathrm{h} \text {, } \\
\mathrm{C}_{\max }, 113 \pm 107 \mathrm{nmol} / \mathrm{L} \text {, at } \mathrm{t}_{\max } \text { of } 3.7 \pm 2.4 \mathrm{~h}\end{array}$ & [133] \\
\hline $\begin{array}{l}\text { Mangosteen beverage con- } \\
\text { taining mangosteen, aloe vera, } \\
\text { multivitamins, and green tea } \\
\left(\text { Verve }^{\circledR}\right)\end{array}$ & Oral & $\begin{array}{l}245 \mathrm{~mL} / \text { person/ } \\
\text { day for } 30 \text { days }\end{array}$ & $\begin{array}{l}\text { Decreased levels of serum CRP levels; en- } \\
\text { hanced antioxidant capacity; immunity bio- } \\
\text { markers IgA, IgG, IgM, C } 3 \text { and C } 4 \text { were not } \\
\text { affected; no side effects on human hepatic } \\
\text { and kidney functions }\end{array}$ & [134] \\
\hline
\end{tabular}

probably enhancing the antitumor efficacy. Zhao et al. [139] employed a soft capsule with vegetable oil as the dispersion matrix to improve the bioavailability of $\alpha-\mathrm{MG}$, and finally the absolute bioavailability was effectively improved.

\section{Conclusion and Future Directions}

The high morbidity and mortality of cancer due to the current unsatisfactory anticancer strategies has forced researchers to examine preventive approaches as well as alternative treatments. Chemoprevention by utilization of dietary phytochemicals has emerged as an economic and practicable strategy for cancer control and management. As described in the review, the data derived from various cancer cell lines as well as chemically-induced tumors and implanted tumors in animal models has shown that $\alpha$-MG could effectively inhibit the process of carcinogenesis with a pleiotropic mode of action. According to the drug development pipeline, however, $\alpha$-MG is still at the preclinical stage now, at which point pharmacodynamics, toxicology, and pharmacokinetic studies should be extensively performed before the drug can enter into the clinical testing phase.

The chemopreventive activities of $\alpha$-MG are largely due to its inhibition of abnormal cell proliferation through the regulation of cell cycle and apoptosis as evidenced by a large number of studies discussed here. Also, the excellent antimetastatic activities have been proven in various types of cancer cells and animal models. Perhaps, future research should further characterize the exact mechanisms by which $\alpha-\mathrm{MG}$ exerts its effects on the cell cycle, apoptosis, angiogenesis, and metastasis. The anticarcinogenic activities of $\alpha$-MG include the mitigation of oxidative stress and inhibition of metabolic activation of carcinogens. Although $\alpha-\mathrm{MG}$ is known to scavenge ROS and modulate oxidative stress-related enzymes, it is necessary to further identify the underlying signaling pathways, thereby improving the therapeutic modalities of this compound. Besides, the studies regarding its effects on phase I and II enzymes and upstream signaling pathways associated with the modulation of carcinogen biotransformation are limited, and hence much particular attention to this area is mandatory.

Until now, only limited information with respect to the pharmacokinetic properties of $\alpha$-MG is available. In particular, many questions with respect to $\alpha$-MG's metabolism and excretion remain to be determined. It is still to be clarified whether $\alpha$-MG conjugates are transported to tissues or directly excreted, and how biological activities will change after conjugation. Systematic pharmacokinetic studies about the establishment of an appropriate route of administration and effective concentration range under physiological conditions of $\alpha$-MG have not yet been performed. Despite being well tolerated in most preclinical studies, the toxicological profile, especially chronic toxicity of ingestion, remains unclear now. This current research gap in pharmacokinetics and toxicology has hindered the clinical application of $\alpha$ MG. Therefore, extensive animal studies, long-term epidemiologic studies, and controlled clinical trials are required to further establish its safety and chemopreventive efficacy. Pharmacokinetic data from studies with murine models indicates a poor bioavailability of $\alpha$-MG. Another future research area would be the design of novel $\alpha-M G$ analogs with improved pharmacokinetic and pharmacodynamic properties. Additionally, active research should also be directed at novel drug formulation and delivery systems, such as solid dispersion and nanoparticle formulations of $\alpha$ MG, which would enhance its targeting effect, bioavailability, and efficacy. Anyway, the current available preclinical and mechanistic 
data has indicated that $\alpha$-MG is a promising candidate to be used in cancer chemoprevention.

\section{Supporting information}

Diagrams showing the biochemical basis of $\alpha$-MG as a cancer chemopreventive agent, how $\alpha$-MG acts as a cancer-blocking agent obstructing cancer initiation, and how $\alpha$-MG acts as a cancer-suppressing agent retarding cancer promotion and progression are available as Supporting Information.

\section{Acknowledgements}

The authors acknowledge the Leading Entrepreneurship Talents Program of Nanjing, China (No.2013B14007) for the financial support.

\section{Conflict of Interest}

The authors confirm that this article content has no conflicts of interest.

\section{References}

[1] El-Gamal $\mathrm{Ml}$, Oh CH. Synthesis, in vitro antiproliferative activity, and in silico studies of fused tricyclic coumarin sulfonate derivatives. Eur J Med Chem 2014; 84: 68-76

[2] Kasala ER, Bodduluru LN, Madana RM, V AK, Gogoi R, Barua CC. Chemopreventive and therapeutic potential of chrysin in cancer: mechanistic perspectives. Toxicol Lett 2015; 233: 214-225

[3] Ferlay J, Soerjomataram I, Dikshit R, Eser S, Mathers C, Rebelo M, Parkin DM, Forman D, Bray F. Cancer incidence and mortality worldwide: sources, methods and major patterns in GLOBOCAN 2012. Int J Cancer 2015; 136: E359-E386

[4] Singh SR. Cancer stem cells: recent developments and future prospects. Cancer Lett 2013; 338: 1-2

[5] Mahapatra DK, Bharti SK, Asati V. Anti-cancer chalcones: Structural and molecular target perspectives. Eur J Med Chem 2015; 98: 69-114

[6] Neergheen VS, Bahorun T, Taylor EW, Jen LS, Aruoma OI. Targeting specific cell signaling transduction pathways by dietary and medicinal phytochemicals in cancer chemoprevention. Toxicology 2010; 278: 229241

[7] Wu X, Patterson S, Hawk E. Chemoprevention-history and general principles. Best Pract Res Clin Gastroenterol 2011; 25: 445-459

[8] Russo M, Spagnuolo C, Tedesco I, Russo GL. Phytochemicals in cancer prevention and therapy: truth or dare? Toxins (Basel) 2010; 2: 517-551

[9] Aggarwal BB, Shishodia S. Molecular targets of dietary agents for prevention and therapy of cancer. Biochem Pharmacol 2006; 71: 1397-1421

[10] Wattenberg LW. Chemoprevention of cancer. Cancer Res 1985; 45: 1-8

[11] Pedraza-Chaverri J, Cardenas-Rodriguez N, Orozco-Ibarra M, Perez-Rojas JM. Medicinal properties of mangosteen (Garcinia mangostana). Food Chem Toxicol 2008; 46: 3227-3239

[12] Garrity AR, Morton GA, Morton JC. Nutraceutical mangosteen composition. US Patent 6730333 B1; 2004

[13] Yeung S. Mangosteen for the cancer patient: facts and myths. J Soc Integr Oncol 2006; 4: 130-134

[14] Shan T, Ma Q, Guo K, Liu J, Li W, Wang F, Wu E. Xanthones from mangosteen extracts as natural chemopreventive agents: potential anticancer drugs. Curr Mol Med 2011; 11: 666-677
[15] Ibrahim MY, Hashim NM, Mariod AA, Mohan S, Abdulla MA, Abdelwahab SI, Arbab IA. $\alpha$-Mangostin from Garcinia mangostana Linn: an updated review of its pharmacological properties. Arab J Chem 2016; 3: 317-329

[16] Kwon KH, Barve A, Yu S, Huang MT, Kong ANT. Cancer chemoprevention by phytochemicals: potential molecular targets, biomarkers and animal models. Acta Pharmacol Sin 2007; 28: 1409-1421

[17] Arakaki J, Sunagawa N, Chiba I, Morita N, Kinjo T, Kaneshiro T, Morioka T, Nishimaki T, Yoshimi N. Inhibitory effect of $\alpha$-mangostin on colon carcinogenesis induced by azoxymethane plus dextran sulfate sodium in CD1 (ICR) mice. Cancer Res 2007; 67: Abstract 4974

[18] Nabandith V, Suzui M, Morioka T, Kaneshiro T, Kinjo T, Matsumoto K, Akao Y, linuma M, Yoshimi N. Inhibitory effects of crude $\alpha$-mangostin, a xanthone derivative, on two different categorie of colon preneoplastic lesions induced by 1, 2-dimethylhydrazine in the rat. Asian Pac J Cancer Prev 2004; 5: 433-438

[19] Aisha AF, Abu-Salah KM, Ismail Z, Majid AM. In vitro and in vivo anti-colon cancer effects of Garcinia mangostana xanthones extract. BMC Complement Altern Med 2012; 12: 104

[20] Chitchumroonchokchai C, Thomas-Ahner JM, Li J, Riedl KM, Nontakham J, Suksumrarn S, Clinton SK, Kinghorn AD, Failla ML. Anti-tumorigenicity of dietary alpha-mangostin in an HT-29 colon cell xenograft model and the tissue distribution of xanthones and their phase II metabolites. Mol Nutr Food Res 2013; 57: 203-211

[21] Johnson J], Petiwala SM, Syed DN, Rasmussen JT, Adhami VM, Siddiqui IA, Kohl AM, Mukhtar $\mathrm{H}$. alpha-Mangostin, a xanthone from mangosteen fruit, promotes cell cycle arrest in prostate cancer and decreases xenograft tumor growth. Carcinogenesis 2012; 33: 413-419

[22] Hsieh SC, Huang MH, Cheng CW, Hung JH, Yang SF, Hsieh YH. $\alpha$-Mangostin induces mitochondrial dependent apoptosis in human hepatoma SK-Hep-1 cells through inhibition of p 38 MAPK pathway. Apoptosis 2013; 18: 1548-1560

[23] Lee HN, Jang HY, Kim HJ, Shin SA, Choo GS, Park YS, Kim SK, Jung JY. Antitumor and apoptosis-inducing effects of $\alpha$-mangostin extracted from the pericarp of the mangosteen fruit (Garcinia mangostana L.) in YD-15 tongue mucoepidermoid carcinoma cells. Int J Mol Med 2016; 37: 939-948

[24] Chao AC, Hsu YL, Liu CK, Kuo PL. $\alpha$-Mangostin, a dietary xanthone, induces autophagic cell death by activating the AMP-activated protein kinase pathway in glioblastoma cells. J Argric Food Chem 2011; 59: 2086-2096

[25] Hafeez BB, Mustafa A, Fischer JW, Singh A, Zhong W, Shekhani MO, Meske L, Havighurst T, Kim K, Verma AK. $\alpha$-Mangostin: a dietary antioxidant derived from the pericarp of Garcinia mangostana L. inhibits pancreatic tumor growth in xenograft mouse model. Antioxid Redox Signal 2014; 21: 682-699

[26] Hafeez BB, Fischer JW, Mustafa A, Zhong W, Verma AK. $\alpha$-Mangostin, a dietary xanthone, inhibits ectopic xenograft growth of pancreatic cancer cells in an athymic nude mice. Cancer Res 2012; 72: Abstract 5418

[27] Shibata MA, linuma M, Morimoto J, Kurose H, Akamatsu K, Okuno $Y$, Akao Y, Otsuki Y. $\alpha$-Mangostin extracted from the pericarp of the mangosteen (Garcinia mangostana Linn.) reduces tumor growth and lymph node metastasis in an immunocompetent xenograft model of metastatic mammary cancer carrying a p 53 mutation. BMC Med 2011; 9: 69

[28] Lee JS, Surh Y]. Nrf2 as a novel molecular target for chemoprevention. Cancer Lett 2005; 224: 171-184

[29] Klaunig JE, Kamendulis LM. The role of oxidative stress in carcinogenesis. Annu Rev Pharmacol Toxicol 2004; 44: 239-267

[30] Aggarwal BB, Shishodia S, Sandur SK, Pandey MK, Sethi G. Inflammation and cancer: how hot is the link? Biochem Pharmacol 2006; 72: 16051621

[31] Signorelli P, Ghidoni R. Resveratrol as an anticancer nutrient: molecular basis, open questions and promises. J Nutr Biochem 2005; 16: 449-466 
[32] Jung HA, Su BN, Keller W], Mehta RG, Kinghorn AD. Antioxidant xanthones from the pericarp of Garcinia mangostana (Mangosteen). J Agric Food Chem 2006; 54: 2077-2082

[33] Shou M, Korzekwa KR, Krausz KW, Buters J, Grogan J, Goldfarb I, Hardwick JP, Gonzalez FJ, Gelboin HV. Specificity of cDNA-expressed human and rodent cytochrome P450 s in the oxidative metabolism of the potent carcinogen 7, 12-dimethylbenz [a] anthracene. Mol Carcinog 1996; 17: 241-249

[34] Balunas M], Su B, Brueggemeier RW, Kinghorn AD. Xanthones from the botanical dietary supplement mangosteen (Garcinia mangostana) with aromatase inhibitory activity. J Nat Prod 2008; 71: 1161-1166

[35] Reyes-Fermin LM, Gonzalez-Reyes S, Tarco-Alvarez NG, Hernandez-Nava M, Orozco-Ibarra M, Pedraza-Chaverri J. Neuroprotective effect of $\alpha$ mangostin and curcumin against iodoacetate-induced cell death. Nutr Neurosci 2012; 15: 34-41

[36] Yu BP. Cellular defenses against damage from reactive oxygen species. Physiol Rev 1994; 74: 139-162

[37] Ma Q. Transcriptional responses to oxidative stress: pathological and toxicological implications. Pharmacol Ther 2010; 125: 376-393

[38] Devi Sampath P, Vijayaraghavan K. Cardioprotective effect of $\alpha$-mangostin, a xanthone derivative from mangosteen on tissue defense system against isoproterenol-induced myocardial infarction in rats. J Biochem Mol Toxicol 2007; 21: 336-339

[39] Sampath PD, Kannan V. Mitigation of mitochondrial dysfunction and regulation of eNOS expression during experimental myocardial necrosis by alpha-mangostin, a xanthonic derivative from Garcinia mangostana. Drug Chem Toxicol 2009; 32: 344-352

[40] Buelna-Chontal M, Correa F, Hernández-Reséndiz S, Zazueta C, PedrazaChaverri J. Protective effect of $\alpha$-mangostin on cardiac reperfusion damage by attenuation of oxidative stress. J Med Food 2011; 14: 1370-1374

[41] Márquez-Valadez B, Lugo-Huitrón R, Valdivia-Cerda V, Miranda-Ramírez LR, Pérez-De La Cruz V, González-Cuahutencos O, Rivero-Cruz I, Mata R, Santamaría A, Pedraza-Chaverrí J. The natural xanthone $\alpha$-mangostin reduces oxidative damage in rat brain tissue. Nutr Neurosci 2009; 12: 35-42

[42] Yoshikawa M, Harada E, Miki A, Tsukamoto K, Liang S, Yamahara J, Murakami N. Antioxidant constituents from the fruit hulls of mangosteen (Garcinia mangostana L.) originating in Vietnam. Yakugaku Zasshi 1994; 114: 129-133

[43] Fan CT, Su J. Antioxidative mechanism of isolated componentss from methanol extract of fruit hulls of Garcinia mongostana L. J Chinese Agr Chem Soc 1997; 35: 540-551

[44] Williams P, Ongsakul M, Proudfoot ], Croft K, Beilin L. Mangostin inhibits the oxidative modification of human low density lipoprotein. Free Radic Res 1995; 23: 175-184

[45] Mahabusarakam W, Proudfoot J, Taylor W, Croft K. Inhibition of lipoprotein oxidation by prenylated xanthones derived from mangostin. Free Radic Res 2000; 33: 643-659

[46] Pedraza-Chaverri ], Reyes-Fermin LM, Nolasco-Amaya EG, Orozco-Ibarra M, Medina-Campos ON, Gonzalez-Cuahutencos O, Rivero-Cruz I, Mata R. ROS scavenging capacity and neuroprotective effect of alpha-mangostin against 3-nitropropionic acid in cerebellar granule neurons. Exp Toxicol Pathol 2009; 61: 491-501

[47] Sun D, Zhang S, Wei Y, Yin L. Antioxidant activity of mangostin in cellfree system and its effect on K562 leukemia cell line in photodynamic therapy. Acta Biochim Biophys Sin 2009; 41: 1033-1043

[48] Cui ], Hu W, Cai Z, Liu Y, Li S, Tao W, Xiang H. New medicinal properties of mangostins: analgesic activity and pharmacological characterization of active ingredients from the fruit hull of Garcinia mangostana L. Pharmacol Biochem Behav 2010; 95: 166-172

[49] Martínez A, Galano A, Vargas R. Free radical scavenger properties of $\alpha$ mangostin: thermodynamics and kinetics of HAT and RAF mechanisms. J Phys Chem B 2011; 115: 12591-12598
[50] Tanaka R. Inhibitory effects of xanthone on paraquat- and $\mathrm{NaNO}_{2}$-induced genotoxicity in cultured cells. J Toxicol Sci 2007; 32: 571-574

[51] Martínez-Abundis E, García N, Correa F, Hernández-Reséndiz S, PedrazaChaverri J, Zazueta C. Effects of $\alpha$-mangostin on mitochondrial energetic metabolism. Mitochondrion 2010; 10: 151-157

[52] Jenkins RW, Canals D, Hannun YA. Roles and regulation of secretory and lysosomal acid sphingomyelinase. Cell Signal 2009; 21: 836-846

[53] Corda S, Laplace C, Vicaut E, Duranteau ]. Rapid reactive oxygen species production by mitochondria in endothelial cells exposed to tumor necrosis factor- $\alpha$ is mediated by ceramide. Am J Respir Cell Mol Biol 2001; 24: $762-768$

[54] Lecour S, Van Der Merwe E, Opie LH, Sack MN. Ceramide attenuates hypoxic cell death via reactive oxygen species signaling. J Cardiovasc Pharm 2006; 47: 158-163

[55] Zhang DX, Zou AP, Li PL. Ceramide-induced activation of NADPH oxidase and endothelial dysfunction in small coronary arteries. Am J Physiol Heart Circ Physiol 2003; 284: H605-H612

[56] Okudaira C, Ikeda Y, Kondo S, Furuya S, Hirabayashi Y, Koyano T, Saito Y Umezawa K. Inhibition of acidic sphingomyelinase by xanthone compounds isolated from Garcinia speciosa. J Enzym Inhib Med Chem 2000; 15: $129-138$

[57] Yang K, Zhang KJ, Hu SY, Gu QL, Dong JB, Wang JX. Design, synthesis and biological activity of acid sphingomyelinase inhibitors. Chem J Chin Univ 2015; 36: 279-286

[58] Marquez-Valadez B, Maldonado PD, Galvan-Arzate S, Mendez-Cuesta LA Perez-De La Cruz V, Pedraza-Chaverri J, Chanez-Cardenas ME, Santamaria A. $\alpha$-Mangostin induces changes in glutathione levels associated with glutathione peroxidase activity in rat brain synaptosomes. Nutr Neurosci 2012; 15: 13-19

[59] Hussain SP, Harris CC. Inflammation and cancer: an ancient link with novel potentials. Int J Cancer 2007; 121: 2373-2380

[60] Reuter S, Gupta SC, Chaturvedi MM, Aggarwal BB. Oxidative stress, inflammation, and cancer: how are they linked? Free Radic Biol Med 2010; 49: 1603-1616

[61] Tewtrakul S, Wattanapiromsakul C, Mahabusarakam W. Effects of com pounds from Garcinia mangostana on inflammatory mediators in RAW264.7 macrophage cells. J Ethnopharmacol 2009; 121: 379-382

[62] Chen LG, Yang LL, Wang CC. Anti-inflammatory activity of mangostins from Garcinia mangostana. Food Chem Toxicol 2008; 46: 688-693

[63] Athar M, Back JH, Kopelovich L, Bickers DR, Kim AL. Multiple molecula targets of resveratrol: Anti-carcinogenic mechanisms. Arch Biochem Biophys 2009; 486: 95-102

[64] Atluri N, Holur R, Thirumalanadhuni V, Palempalli UMD. Modulation of pro-inflammatory genes by $\alpha$-mangostin from Garcinia mangostana. Int J Pharm Sci Invent 2014; 3: 23-29

[65] Navya A, Nanda Kumar Y, Hari Prasad O, Santhrani T, Uma Maheswari Devi P. In vivo and in silico analysis divulges the anti-inflammatory activity of $\alpha$-mangostin. Int J Appl Biotech Biochem 2012; 2: 69-80

[66] Yeung F, Hoberg JE, Ramsey CS, Keller MD, Jones DR, Frye RA, Mayo MW. Modulation of NF-kappaB-dependent transcription and cell survival by the SIRT1 deacetylase. EMBO J 2004; 23: 2369-2380

[67] Franceschelli S, Pesce M, Ferrone A, Patruno A, Livia P, Carlucci G, Ferrone V, Carlucci M, De Lutiis MA, Grilli A, Felaco M, Speranza L. A novel biological role of alpha-mangostin in modulating inflammatory response through the activation of SIRT-1 signaling pathway. J Cell Physiol 2016; 231: 2439-2451

[68] Ramos S. Cancer chemoprevention and chemotherapy: dietary polyphenols and signalling pathways. Mol Nutr Food Res 2008; 52: 507-526

[69] Lei B, Xi L, Li ], Liu H, Yao X. Global, local and novel consensus quantitative structure-activity relationship studies of 4-(phenylaminomethylene) isoquinoline-1,3(2H,4H)-diones as potent inhibitors of the cyclin-dependent kinase 4. Anal Chim Acta 2009; 644: 17-24 
[70] Kasala ER, Bodduluru LN, Madana RM, Athira K, Gogoi R, Barua CC. Chemopreventive and therapeutic potential of chrysin in cancer: mechanistic perspectives. Toxicol Lett 2015; 233: 214-225

[71] Johnson J], Petiwala SM, Syed DN, Rasmussen JT, Adhami VM, Siddiqui IA, Kohl AM, Mukhtar H. $\alpha$-Mangostin, a xanthone from mangosteen fruit, promotes cell cycle arrest in prostate cancer and decreases xenograft tumor growth. Carcinogenesis 2012; 33: 413-419

[72] Wang J], Zhang W, Sanderson B]. Altered mRNA expression related to the apoptotic effect of three xanthones on human melanoma SK-MEL-28 cell line. Biomed Res Int 2013; 2013: 715603

[73] Kurose H, Shibata MA, linuma M, Otsuki Y. Alterations in cell cycle and induction of apoptotic cell death in breast cancer cells treated with $\alpha$ mangostin extracted from mangosteen pericarp. J Biomed Biotechnol 2012; 2012: 672428

[74] Xu Q, Ma J, Lei ], Duan W, Sheng L, Chen X, Hu A, Wang Z, Wu Z, Wu E. $\alpha$ Mangostin suppresses the viability and epithelial-mesenchymal transition of pancreatic cancer cells by downregulating the PI3 K/Akt pathway. Biomed Res Int 2014; 2014: 546353

[75] Itahana K, Dimri G, Campisi J. Regulation of cellular senescence by p 53. Eur J Biochem 2001; 268: 2784-2791

[76] Korm S, Jeong HC, Kwon OS, Park JR, Cho H, Kim YM, Chin YW, Cha HJ. $\alpha$ Mangostin induces G1 cell cycle arrest in HCT116 cells through p38MAPK-p 16INK4 a pathway. RSC Adv 2015; 5: 34752-34760

[77] Kim JH, Yoon SY, Kim CN, Joo JH, Moon SK, Choe IS, Choe YK, Kim JW. The Bmi-1 oncoprotein is overexpressed in human colorectal cancer and correlates with the reduced p 16INK4 a/p 14ARF proteins. Cancer Lett 2004; 203: 217-224

[78] Ibrahim MY, Mohd Hashim N, Mohan S, Abdulla MA, Abdelwahab SI, Kamalidehghan B, Ghaderian M, Dehghan F, Ali LZ, Karimian H, Yahayu M, Ee GC, Farjam AS, Mohd Ali H. Involvement of NF-KB and HSP70 signaling pathways in the apoptosis of MDA-MB-231 cells induced by a prenylated xanthone compound, $\alpha$-mangostin, from Cratoxylum arborescens. Drug Des Devel Ther 2014; 8: 2193-2211

[79] Hafeez BB, Dreckschmidt NE, Colson LA, Verma AK. Dietary agent $\alpha$ Mangostin inhibits growth of pancreatic cancer BxPC3 and PANC1 cells and arrests the cell cycle in G0/G1 phase: Involvement of Ras, Hedgehog, NF-KB, and STAT3 signaling networks. Cancer Res 2010; 70: Abstract 3800

[80] Mizushina Y, Kuriyama I, Nakahara T, Kawashima Y, Yoshida H. Inhibitory effects of alpha-mangostin on mammalian DNA polymerase, topoisomerase, and human cancer cell proliferation. Food Chem Toxicol 2013; 59 : 793-800

[81] Aisha AF, Abu-Salah KM, Ismail Z, Majid AM. In vitro and in vivo anti-colon cancer effects of Garcinia mangostana xanthones extract. BMC Complement Altern Med 2012; 12: 104

[82] Watanapokasin R, Jarinthanan F, Jerusalmi A, Suksamrarn S, Nakamura $Y$, Sukseree S, Uthaisang-Tanethpongtamb W, Ratananukul P, Sano T. Potential of xanthones from tropical fruit mangosteen as anti-cancer agents: caspase-dependent apoptosis induction in vitro and in mice. Appl Biochem Biotechnol 2010; 162: 1080-1094

[83] Matsumoto K, Akao Y, Kobayashi E, Ohguchi K, Ito T, Tanaka T, linuma $\mathrm{M}$, Nozawa $\mathrm{Y}$. Induction of apoptosis by xanthones from mangosteen in human leukemia cell lines. J Nat Prod 2003; 66: 1124-1127

[84] Chen J], Long Z], Xu DF, Xiao RZ, Liu LL, Xu ZF, Qiu SX, Lin DJ, Liu Q. Inhibition of autophagy augments the anticancer activity of $\alpha$-mangostin in chronic myeloid leukemia cells. Leuk Lymphoma 2014; 55: 628-638

[85] Menasria F, Azebaze AG, Billard C, Faussat AM, Nkengfack AE, Meyer M, Kolb JP. Apoptotic effects on B-cell chronic lymphocytic leukemia (B-CLL) cells of heterocyclic compounds isolated from Guttiferaes. Leuk Res 2008; 32: 1914-1926

[86] Gross A, McDonnell JM, Korsmeyer S]. BCL-2 family members and the mitochondria in apoptosis. Genes Dev 1999; 13: 1899-1911
[87] Watanapokasin R, Jarinthanan F, Nakamura Y, Sawasjirakij N, Jaratrungtawee A, Suksamrarn S. Effects of $\alpha$-mangostin on apoptosis induction of human colon cancer. World J Gastroenterol 2011; 17: 2086

[88] Krajarng A, Nakamura Y, Suksamrarn S, Watanapokasin R. $\alpha$-Mangostin induces apoptosis in human chondrosarcoma cells through downregulation of ERK/JNK and Akt signaling pathway. J Agric Food Chem 2011; 59: 5746-5754

[89] Matsumoto K, Akao Y, Yi H, Ohguchi K, Ito T, Tanaka T, Kobayashi E, linuma M, Nozawa Y. Preferential target is mitochondria in $\alpha$-mangostin-induced apoptosis in human leukemia HL60 cells. Bioorg Med Chem 2004; 12: 5799-5806

[90] Nakagawa Y, linuma M, Naoe T, Nozawa Y, Akao Y. Characterized mechanism of $\alpha$-mangostin-induced cell death: caspase-independent apoptosis with release of endonuclease-G from mitochondria and increased miR-143 expression in human colorectal cancer DLD-1 cells. Bioorg Med Chem 2007; 15: 5620-5628

[91] Kaomongkolgit R, Chaisomboon N, Pavasant P. Apoptotic effect of alpha-mangostin on head and neck squamous carcinoma cells. Arch Oral Biol 2011; 56: 483-490

[92] Leão M, Gomes S, Pedraza-Chaverri ], Machado N, Sousa E, Pinto M, Inga A, Pereira C, Saraiva L. Alpha-mangostin and gambogic acid as potential inhibitors of the $\mathrm{p} 53-\mathrm{MDM} 2$ interaction revealed by a yeast approach. J Nat Prod 2013; 76: 774-778

[93] Doi H, Shibata MA, Shibata E, Morimoto J, Akao Y, linuma M, Tanigawa N, Otsuki Y. Panaxanthone isolated from pericarp of Garcinia mangostana L. suppresses tumor growth and metastasis of a mouse model of mammary cancer. Anticancer Res 2009; 29: 2485-2495

[94] Won YS, Lee JH, Kwon S], Kim JY, Park KH, Lee MK, Seo KI. $\alpha$-Mangostin-induced apoptosis is mediated by estrogen receptor $\alpha$ in human breast cancer cells. Food Chem Toxicol 2014; 66: 158-165

[95] Turcotte S, Giaccia AJ. Targeting cancer cells through autophagy for anticancer therapy. Curr Opin Cell Biol 2010; 22: 246-251

[96] Li G, Petiwala SM, Nonn L, Johnson J]. Inhibition of CHOP accentuates the apoptotic effect of $\alpha$-mangostin from the mangosteen fruit (Garcinia mangostana) in 22Rv1 prostate cancer cells. Biochem Biophys Res Commun 2014; 453: 75-80

[97] Li G, Petiwala SM, Pierce DR, Nonn L, Johnson JJ. Selective modulation of endoplasmic reticulum stress markers in prostate cancer cells by a standardized mangosteen fruit extract. PLoS One 2013; 8: e81572

[98] Ferrara N. VEGF and the quest for tumour angiogenesis factors. Nat Rev Cancer 2002; 2: 795-803

[99] Olsson AK, Dimberg A, Kreuger ], Claesson-Welsh L. VEGF receptor signalling - in control of vascular function. Nat Rev Mol Cell Biol 2006; 7: 359-371

[100] Arifianti L, Rofida S, Sukardiman NCZ. Antiangiogenesis from pericarp of mangosteen on T47D breast cancer. E-Journal Planta Husada 2014; 2: $12-15$

[101] Lei], Huo X, Duan W, Xu Q, Li R, Ma J, Li X, Han L, Li W, Sun H, Wu E, Ma Q. alpha-Mangostin inhibits hypoxia-driven ROS-induced PSC activation and pancreatic cancer cell invasion. Cancer Lett 2014; 347: 129-138

[102] Jittiporn K, Suwanpradid J, Patel C, Rojas M, Thirawarapan S, Moongkarndi P, Suvitayavat W, Caldwell RB. Anti-angiogenic actions of the mangosteen polyphenolic xanthone derivative $\alpha$-mangostin. Microvasc Res 2014; 93: 72-79

[103] Shiozaki T, Fukai M, Hermawati E, Juliawaty LD, Syah YM, Hakim EH, Puthongking P, Suzuki T, Kinoshita K, Takahashi K, Koyama K. Anti-angiogenic effect of $\alpha$-mangostin. J Nat Med 2013; 67: 202-206

[104] Kundu JK, Surh Y]. Cancer chemopreventive and therapeutic potential of resveratrol: mechanistic perspectives. Cancer Lett 2008; 269: 243261

[105] Wang JJ, Sanderson BJ, Zhang W. Significant anti-invasive activities of $\alpha$-mangostin from the mangosteen pericarp on two human skin cancer cell lines. Anticancer Res 2012; 32: 3805-3816 
[106] Kaomongkolgit R. Alpha-mangostin suppresses MMP-2 and MMP-9 expression in head and neck squamous carcinoma cells. Odontology 2013; 101: 227-232

[107] Shih YW, Chien ST, Chen PS, Lee JH, Wu SH, Yin LT. $\alpha$-Mangostin suppresses phorbol 12-myristate 13-acetate-induced MMP-2/MMP-9 expressions via $\alpha v \beta 3$ integrin/FAK/ERK and NF- $K B$ signaling pathway in human lung adenocarcinoma A549 cells. Cell Biochem Bioph 2010; 58: $31-44$

[108] Hung SH, Shen KH, Wu CH, Liu CL, Shih YW. $\alpha$-Mangostin suppresses PC-3 human prostate carcinoma cell metastasis by inhibiting matrix metalloproteinase-2/9 and urokinase-plasminogen expression through the JNK signaling pathway. J Agric Food Chem 2009; 57 : 1291-1298

[109] Yuan J, Wu Y, Lu G. $\alpha$-Mangostin suppresses lipopolysaccharide-induced invasion by inhibiting matrix metalloproteinase-2/9 and increasing E-cadherin expression through extracellular signal-regulated kinase signaling in pancreatic cancer cells. Oncology Lett 2013; 5: 1958-1964

[110] Sanchez-Perez Y, Morales-Barcenas R, Garcia-Cuellar CM, Lopez-Marure R, Calderon-Oliver M, Pedraza-Chaverri J, Chirino YI. The $\alpha$-mangostin prevention on cisplatin-induced apoptotic death in LLC-PK1 cells is associated to an inhibition of ROS production and p 53 induction. Chem Biol Interact 2010; 188: 144-150

[111] Perez-Rojas JM, Cruz C, Garcia-Lopez P, Sanchez-Gonzalez DJ, MartinezMartinez CM, Ceballos G, Espinosa M, Melendez-Zajgla J, Pedraza-Chaverri J. Renoprotection by $\alpha$-mangostin is related to the attenuation in renal oxidative/nitrosative stress induced by cisplatin nephrotoxicity. Free Radic Res 2009; 43: 1122-1132

[112] Tangpong J, Miriyala S, Noel T, Sinthupibulyakit C, Jungsuwadee P, Clair DS. Doxorubicin-induced central nervous system toxicity and protection by xanthone derivative of Garcinia mangostana. Neuroscience 2011; 175: 292-299

[113] Boutros T, Chevet E, Metrakos P. Mitogen-activated protein (MAP) kinase/MAP kinase phosphatase regulation: roles in cell growth, death, and cancer. Pharmacol Rev 2008; 60: 261-310

[114] Agarwal A, Das K, Lerner N, Sathe S, Cicek M, Casey G, Sizemore N. The AKT/I kappa B kinase pathway promotes angiogenic/metastatic gene expression in colorectal cancer by activating nuclear factor-kappa B and beta-catenin. Oncogene 2005; 24: 1021-1031

[115] Kumazaki M, Noguchi S, Yasui Y, Iwasaki J, Shinohara H, Yamada N, Akao Y. Anti-cancer effects of naturally occurring compounds through modulation of signal transduction and miRNA expression in human coIon cancer cells. J Nutr Biochem 2013; 24: 1849-1858

[116] Surh Y]. Cancer chemoprevention with dietary phytochemicals. Nat Rev Cancer 2003; 3: 768-780

[117] Lee YB, Ko KC, Shi MD, Liao YC, Chiang TA, Wu PF, Shih YX, Shih YW. $\alpha$ Mangostin, a novel dietary xanthone, suppresses TPA-mediated MMP-2 and MMP-9 expressions through the ERK signaling pathway in MCF-7 human breast adenocarcinoma cells. J Food Sci 2010; 75: H13-H23

[118] Shan T, Cui X, Li W, Lin W, Lu Hw, Li Y, Chen X, Wu T. $\alpha$-Mangostin suppresses human gastric adenocarcinoma cells in vitro via blockade of Stat3 signaling pathway. Acta Pharmacol Sin 2014; 35: 1065-1073

[119] Ibrahim MY, Hashim NM, Mohan S, Abdulla MA, Abdelwahab SI, Arbab IA, Yahayu M, Ali LZ, Ishag OE. $\alpha$-Mangostin from Cratoxylum arborescens: an in vitro and in vivo toxicological evaluation. Arabian J Chem 2015; 8: 129-137

[120] Jujun P, Pootakham K, Pongpaibul Y, Duangrat C, Tharavichitkul P. Acute and repeated dose 28-day oral toxicity study of Garcinia mangostana Linn. rind extract. CMU J Nat Sci 2008; 7: 199-208

[121] Bunyong R, Chaijaroenkul W, Plengsuriyakarn T, Na-Bangchang K. Antimalarial activity and toxicity of Garcinia mangostana Linn. Asian Pac J Trop Med 2014; 7: 693-698

[122] Hutadilok-Towatana N, Reanmongkol W, Wattanapiromsakul C, Bunkrongcheap R. Acute and subchronic toxicity evaluation of the hydro- ethanolic extract of mangosteen pericarp. J Med Plant Res 2010; 4: 969-974

[123] Gutierrez-Orozco F, Thomas-Ahner JM, Berman-Booty LD, Galley JD, Chitchumroonchokchai C, Mace T, Suksamrarn S, Bailey MT, Clinton SK, Lesinski GB, Failla ML. Dietary alpha-mangostin, a xanthone from mangosteen fruit, exacerbates experimental colitis and promotes dysbiosis in mice. Mol Nutr Food Res 2014; 58: 1226-1238

[124] Gutierrez-Orozco F, Thomas-Ahner JM, Galley JD, Bailey MT, Clinton SK, Lesinski GB, Failla ML. Intestinal microbial dysbiosis and colonic epithelial cell hyperproliferation by dietary alpha-mangostin is independent of mouse strain. Nutrients 2015; 7: 764-784

[125] Bumrungpert A, Kalpravidh RW, Suksamrarn S, Chaivisuthangkura A Chitchumroonchokchai C, Failla ML. Bioaccessibility, biotransformation, and transport of $\alpha$-mangostin from Garcinia mangostana (Mangosteen) using simulated digestion and Caco-2 human intestinal cells. Mol Nutr Food Res 2009; 53: S54-S61

[126] Gutierrez-Orozco F, Chitchumroonchokchai C, Lesinski GB, Suksamrarn S, Failla ML. $\alpha$-Mangostin: anti-inflammatory activity and metabolism by human cells. J Agric Food Chem 2013; 61: 3891-3900

[127] Choi YH, Han SY, Kim Y], Kim YM, Chin YW. Absorption, tissue distribution, tissue metabolism and safety of $\alpha$-mangostin in mangosteen extract using mouse models. Food Chem Toxicol 2014; 66: 140-146

[128] Han SY, You BH, Kim YC, Chin YW, Choi YH. Dose-independent ADME properties and tentative identification of metabolites of alpha-mangostin from Garcinia mangostana in mice by automated microsampling and UPLC-MS/MS methods. PLoS One 2015; 10: e0131587

[129] Li L, Han AR, Kinghorn AD, Frye RF, Derendorf H, Butterweck V. Pharmacokinetic properties of pure xanthones in comparison to a mangosteen fruit extract in rats. Planta Med 2013; 79: 646-653

[130] Tang YP, Li PG, Kondo M, Ji HP, Kou Y, Ou B. Effect of a mangosteen dietary supplement on human immune function: a randomized, double-blind, placebo-controlled trial. J Med Food 2009; 12: 755-763

[131] Kondo M, Zhang L, Ji H, Kou Y, Ou B. Bioavailability and antioxidant effects of a xanthone-rich Mangosteen (Garcinia mangostana) product in humans. J Agric Food Chem 2009; 57: 8788-8792

[132] Xie Z, Sintara M, Chang T, Ou B. Functional beverage of Garcinia mangostana (mangosteen) enhances plasma antioxidant capacity in healthy adults. Food Sci Nutr 2015; 3: 32-38

[133] Chitchumroonchokchai C, Riedl KM, Suksumrarn S, Clinton SK, Kinghorn AD, Failla ML. Xanthones in mangosteen juice are absorbed and partially conjugated by healthy adults. J Nutr 2012; 142: 675-680

[134] Xie Z, Sintara M, Chang T, Ou B. Daily consumption of a mangosteenbased drink improves in vivo antioxidant and anti-inflammatory biomarkers in healthy adults: a randomized, double-blind, placebo-controlled clinical trial. Food Sci Nutr 2015; 3: 342-348

[135] Li L, Brunner I, Han AR, Hamburger M, Kinghorn AD, Frye R, Butterweck $V$. Pharmacokinetics of $\alpha$-mangostin in rats after intravenous and oral application. Mol Nutr Food Res 2011; 55 Suppl. 1: S67-74

[136] Petiwala SM, Li G, Ramaiya A, Kumar A, Gill RK, Saksena S, Johnson JJ. Pharmacokinetic characterization of mangosteen (Garcinia mangostana) fruit extract standardized to $\alpha$-mangostin in C57BL/6 mice. Nutr Res 2014; 34: 336-345

[137] Fei X, Jo M, Lee B, Han SB, Lee K, Jung JK, Seo SY, Kwak YS. Synthesis of xanthone derivatives based on $\alpha$-mangostin and their biological evaluation for anti-cancer agents. Bioorg Med Chem Lett 2014; 24: $2062-$ 2065

[138] Aisha AF, Ismail Z, Abu-Salah KM, Majid AM. Solid dispersions of alphamangostin improve its aqueous solubility through self-assembly of nanomicelles. J Pharm Sci 2012; 101: 815-825

[139] Zhao Y, Tang G, Tang Q, Zhang J, Hou Y, Cai E, Liu S, Lei D, Zhang L, Wang $S$. A method of effectively improved alpha-mangostin bioavailability. Eur J Drug Metab Pharmacokinet 2016; 41: 605-613 